\title{
Synthesis and structure of novel ferrocene-containing $\beta$-carbolines including polycondensed derivatives with the elements of planar-, central- and conformational chirality
}

\author{
Z. Kovács ${ }^{\mathrm{a}}$, T. Jernei ${ }^{\mathrm{a}}$, D. Katona ${ }^{\mathrm{a}}$, L. Kocsis ${ }^{\mathrm{a}, \mathrm{b}}$, A. Csámpai ${ }^{\mathrm{a}^{*}}$ \\ ${ }^{a}$ Institute of Chemistry, Eötvös Loránd University, P. O. B. 32, H-1518 Budapest-112, Hungary. \\ ${ }^{b}$ MTA-ELTE Research Group of Peptide Chemistry, P. O. B. 32, H-1518 Budapest-112, Hungary.
}

\begin{abstract}
Employing tryptamine or tryptophane methylester hydrochloride and $\left(S_{p}\right)$-2formylferrocene-1-carboxylate as precursors by means of Pictet-Spengler reactions and subsequent intramolecular acylation effected by cyanuricfluoride or carbonyldiimidazole (CDI), the first representatives of ferrocene-containing $\beta$-carboline derivatives including polycyclic ferroceno/fused lactames, were prepared. In the course of CDI-mediated tandem cyclization of a tryptophane-derived carboxyferrocenyl-substituted $\beta$-carboline, a ring enlargement simultaneously taking place with the loss of the $\eta^{5}-\mathrm{C}_{5} \mathrm{H}_{5} \mathrm{Fe}^{+}$fragment of the fused ferrocene moiety, effected by the coordinating imidazole released from the reagent, led to a $4 H$-cyclopenta[7,8]azonino[5,4$b$ ]indole as a minor product. The constitution and relative configuration of the new compounds with the elements of planar-, central- and conformational chirality were established by NMR methods including HMQC, HMBC and NOESY measurements supported by DFT modeling studies.
\end{abstract}

Keywords: Condensed ferrocene; $\beta$-carboline; Tandem diastereoselective cyclization; Loss of iron from ferrocene; Planar chirality; Conformational chirality; DFT modeling; NMR spectroscopy

\section{Introduction}

There is a continuous interest in the $\beta$-carboline alkaloids representing an important class of synthetic and naturally occurring heterocycles with a wide spectrum of valuable pharmacological properties [1-6]. In the recent decades it was also demonstrated that $\beta$-carboline alkaloids may have a pronounced potential as anti-cancer agents [7-16], which can act through different mechanisms including eg. DNA-intercalation [17], inhibition of Topoisomerase I and II [18] and CDK (cyclindependent kinases) $[19,20]$. On the other hand, it is well documented that the replacement of an aromatic nucleus in certain organic compounds for a ferrocene unit can lead to such products which possess enhanced biological activity relative to that displayed by the parent molecule [21], and a variety of functionalized ferrocenes with relatively simple structures has been shown to exhibit valuable biological effects [22-32]. In this regard our group has also synthesized and characterized a wide variety of ferrocene-containing heterocycles of potential biological importance [33-46] and - in four cases [47-50] - with proved in vitro anticancer activity against human malignant cell lines. Since to our best knowledge metallocene-based $\beta$-carbolines are not known in the literature, in the frame of our ongoing research we targeted the preparation and structural analysis of ferrocene-containing heterocycles with 2,3,4,9-tetrahydro- $1 H$-pyrido[3,4-b]indole residue including diastereomeric $6,7,12,12$ b-tetrahydro- $4 H$-ferroceno[1,2]indolizino[8,7-b]indol-4-ones, the first representatives of novel classes of alkaloid-like fused metallocenes with the elements of planar-, central- and conformational chirality which will be subjected to in vitro anti-cancer assays on selected human malignant cell lines.

Corresponding author: Tel.: +36 1372 2500/6591; Fax: +36 1372 2548; email:

csampai@chem.elte.hu 


\section{Results and Discussion}

\subsection{Optimization of Pictet-Spengler conditions}

At the beginning of the synthetic pathway we searched for optimal conditions for the crucial Pictet-Spengler cyclizations of imines $\mathbf{2 a}, \mathbf{b}$ and $\mathbf{6 a}, \mathbf{b}$ resulted from facile condensations of tryptaminebased amine components with formylferrocene $(\mathbf{1})$ and $\left(S_{\mathrm{p}}\right)$-2-formylferrocene-1-carboxylic acid (5) [46], respectively, (cf. Methods $A$ and $B$, Scheme 1). The cyclization of $\mathbf{2 a}$, selected as model precursor with the simplest structure in hand, was first attempted by four methods $(C-G)$ employing different acidic conditions to construct 1 -ferrocenyl-2,3,4,9-tetrahydro- $1 H$-pyrido[3,4- $b]$ indole $3 \mathbf{a}$. Since the prolonged treatment $(24 \mathrm{~h})$ of $\mathbf{2 a}$ with acetic acid at reflux temperature proved to be the most efficient protocol (Method $G$ ) to promote the formation of 3a (isolated yield 80\%), the same conditions were applied for the cyclization of iminoester $\mathbf{2 b}$ affording an approximately 5:1 mixture of diastereomers $\mathbf{3 b}$ and $\mathbf{4 b}$. The cyclizations of tryptophane-based imines $\mathbf{6 a}, \mathbf{b}$, were also performed under the conditions of Method $G$ resulting in zwitterionic $\beta$-carboline carboxylates as mixtures of diastereomeric pairs $\mathbf{7 a} / \mathbf{8 a}$ and $\mathbf{7 b} / \mathbf{8 b}$, respectively. Although $\mathbf{8 a}$ could be separated as a minor product, the ester derivatives $\mathbf{7 b}$ and $\mathbf{8 b}$ were isolated in comparable yields (33\% and 28\%, respectively).

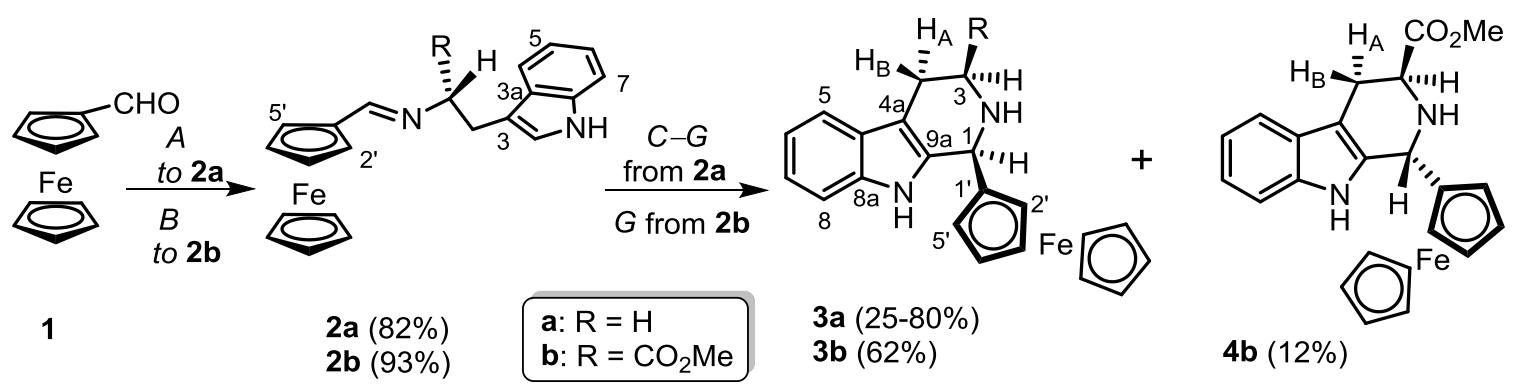

(Although it was obtained as a racemic mixture, for the sake of simplicity $\mathbf{3 a}$ is represented as a single enantiomer .)

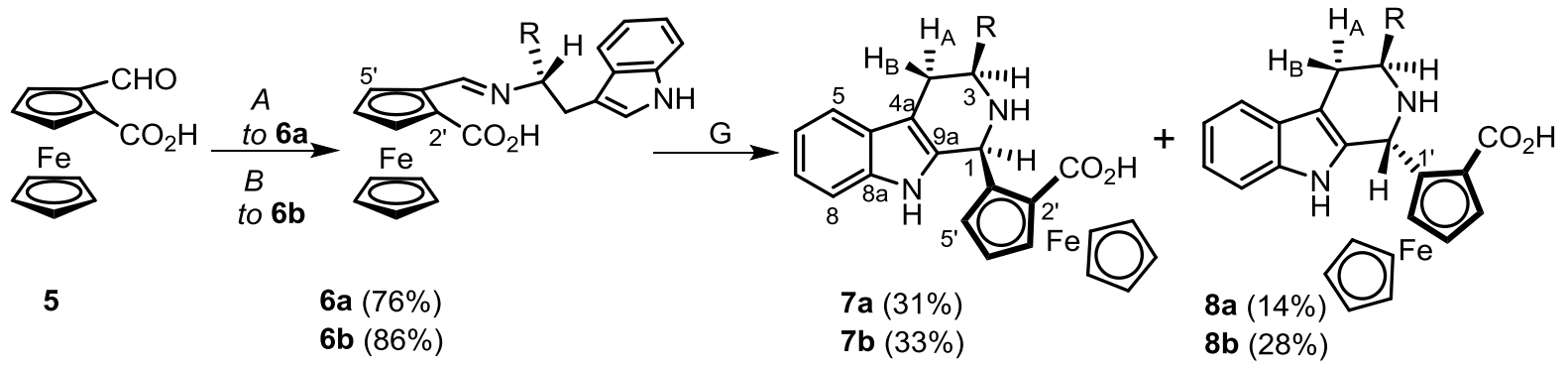

Reaction conditions: A) Tryptamine, EtOH, reflux $4 \mathrm{~h}, \mathrm{Ar} ; B) \mathrm{L}$-Tryptophane methylester hydrochloride, DCM, $\mathrm{Na}_{2} \mathrm{CO}_{3}$, reflux 30 min. Ar; C) $\mathrm{HClO} / \mathrm{EtOH}$, reflux, 24h, Ar; D) $\mathrm{HClO}_{4} / \mathrm{AcOH}$, reflux, 4h, Ar; E) TFA AcOH, reflux, 4h, Ar; F) $\mathrm{H}_{3} \mathrm{BO}_{3} / \mathrm{AcOH}$, reflux, 4h, Ar; G) $\mathrm{AcOH}$, reflux, $24 \mathrm{~h}, \mathrm{Ar}$.

\section{Scheme 1}

With the intention of constructing novel ferroceno-fused ring systems with alkaloid-like structures of potential biological interest first we attempted the cyclization of $7 \mathbf{a}$ by two versions of carboxyl-activation effected by cyanuricfluoride and carbonyldiimidazole (CDI) in the presence of catalytic amount of triethylamine hydrochloride representing Methods $H$ and $I$, respectively (Scheme 2). The reactions gave the fused lactame 9a, with " $S$ "-configuration at the $\mathrm{C} 12 \mathrm{~b}$ stereogenic center and " $M$ " helical chirality associated with the conformation adopted by the tetrahydropyridine ring (referred as ring $C$ in the subsequent discussion), in mediocre yields (45\% and 60\%). The analogous cyclization

Corresponding author: Tel.: +36 1372 2500/6591; Fax: +36 1372 2548; email:

csampai@chem.elte.hu 
of 8a was carried out by Method $I$ resulting in diastereomeric lactame 12a with " $R$ "-configuration at the $\mathrm{C} 12 \mathrm{~b}$ stereogenic center and " $P$ " helical chirality of ring $C$ in acceptable yield (44\%). (The structure determination of the fused lactames will be discussed in detail in the next session.) We also checked the accessibility of $\mathbf{9 a}$ and $\mathbf{1 2 a}$ by a reverse sequence involving primary acylation followed by acid-catalyzed tandem cyclization. However, amide 11 obtained by a facile reaction of tryptamine with $\left(S_{p}\right)$-2-formyl-1-fluorocarbonylferrocene (10) [46] in THF (Method $J$ ) resisted to any further conversions under each condition proved to be efficient in promoting Pictet-Spengler cyclization of imine-type substrates (Scheme 2).

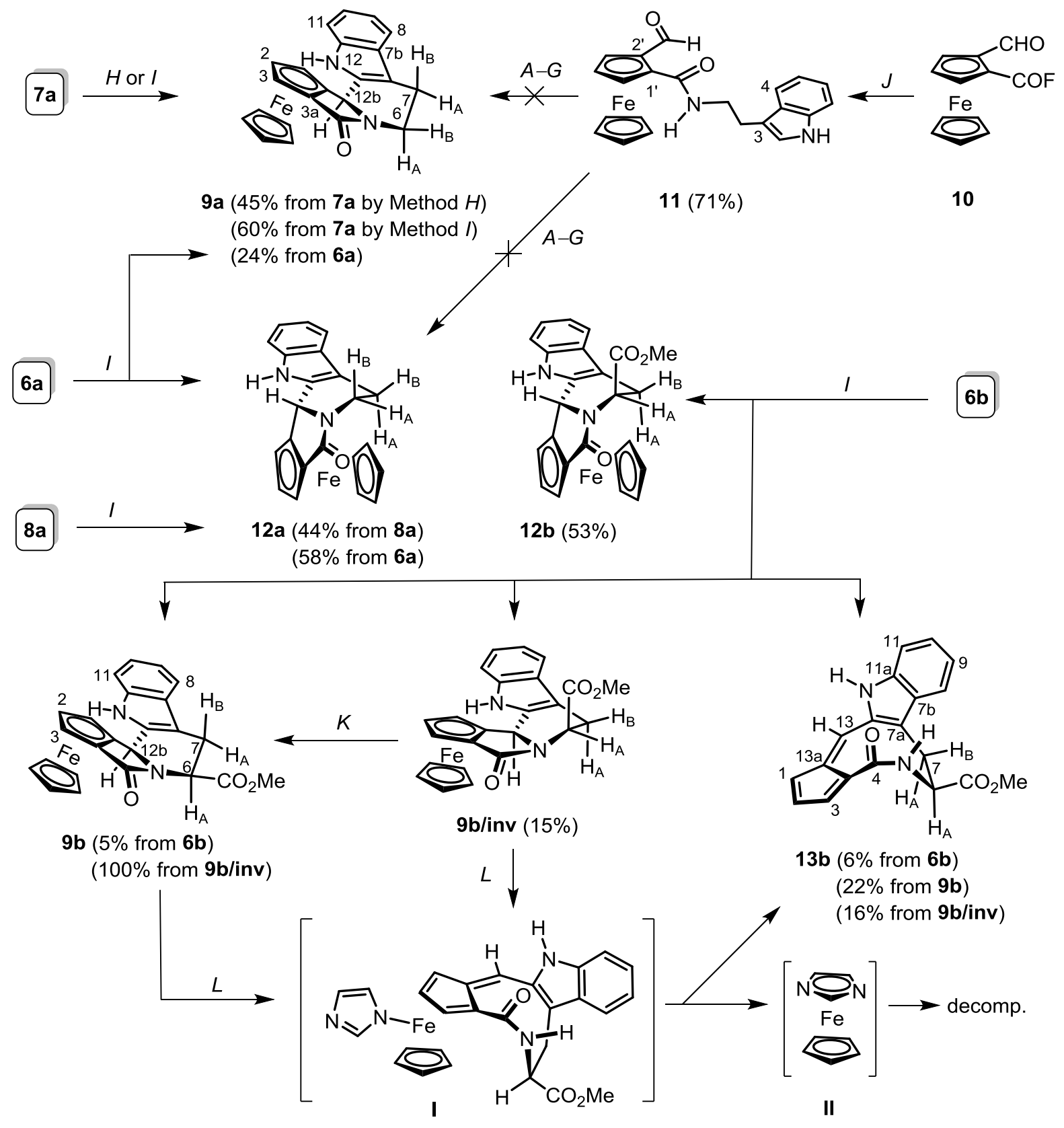

Reaction conditions:

$A-G$ : cf. Scheme 1; $H$ : cyanuricfluoride, DCM, rt, 24 h, Ar; I: i.) CDI (1.2 eq.) / $\mathrm{Et}_{3} \mathrm{~N} . \mathrm{HCl}\left(0.1\right.$ eq.), DMF $50^{\circ} \mathrm{C}, 30$ min., Ar; ii.) $\mathrm{MeOH}$, rt, Ar; J: tryptamine, THF, rt, 24 h, Ar; K: DMSO- $d_{6}, 90^{\circ} \mathrm{C}, 30 \mathrm{~min}$.; L: imidazole/DMF $110^{\circ} \mathrm{C}, 20 \mathrm{~min}$. Ar.

\section{Scheme 2}

Finally, a third version of sequential cyclization procedure employing Method $I$ based on primary carboxyl-activation was attempted to convert imine $\mathbf{6 a}$ into fused lactames (9a and 12a) in a Corresponding author: Tel.: +36 1372 2500/6591; Fax: +36 1372 2548; email: 
single operation. To our surprise, the reaction resulted in diastereomer 12a as the major product (58\%), while 9a was formed as the minor component isolated in low yield (24\%). This one-pot protocol also proved to be successful in promoting a tandem cyclization of tryptophane-based imine 6b to construct diastereomeric esters 12b (53\%), 9b (5\%) and 9b/inv (15\%). Pointing to the relative stability of the separable conformers, on heating in DMSO- $d_{6}$ solution in an NMR tube at $90{ }^{\circ} \mathrm{C}$ under an argon atmosphere for ca. $30 \mathrm{~min}$ (Method $K$ ), 9b/inv with " $P$ " helical chirality of ring $C$ was completely transformed into $\mathbf{9 b}$ with " $M$ " helical chirality of ring $C$.

Besides the ferroceno-fused $\gamma$-lactams a fulvene-fused azoninone (13b) with $E$-lactame unit could also be isolated in low yield $(6 \%)$ from the reaction mixture. The formation of this purely organic product takes place by trans-annular opening of the fused $\gamma$-lactame fragment along the $\mathrm{C} 12 \mathrm{~b}$ N5 bond associated with decomposition of the ferrocene residue, probably induced by imidazole of CDI-origin. This view gains support from the imidazole-mediated transformations of $\mathbf{9 b}$ and $\mathbf{9 b} / \mathbf{i n v}$ carried out in DMF at $110{ }^{\circ} \mathrm{C}$ affording $\mathbf{1 3 b}$ in low yields (22\% and $16 \%$, respectively). The modified conditions employing elevated temperatures or prolonged reaction times did not led to higher yields of 13b, but resulted in the formation of substantial amounts of tarry substances. This transformation can be interpreted by the coordination of imidazole to the $\eta^{5}-\mathrm{C}_{6} \mathrm{H}_{5} \mathrm{Fe}^{+}$residue to give intermediate $\mathbf{I}$ which undergoes fragmentation affording 13b and 1,3-diazaferrocene II. Probably due to its uncontrolled decomposition processes II could not be isolated from the reaction mixture.

The cyclization reactions of esters $\mathbf{7 b}$ and $\mathbf{8 b}$ were also accomplished under the conditions of Method $I$ employing CDI as coupling reagent. Accordingly, the reaction of $\mathbf{7 b}$ afforded a mixture of 9b (37\%), azoninone 13b (9\%) and $\delta$-lactame 14b (22\%) as a result of the acylation of N2- and N9 atoms, respectively (Scheme 3). The decreased propensity of N2 to undergo intramolecular acylation is probably due to the proximity of the bulky methoxycarbonyl group, thus increasing the chance of indole N9 atom to be involved in the cyclization step accompanied by spontaneous dehydrogenation of the tetrahydropyridine ring finally affording $\mathbf{1 4 b}$. Under the same conditions $\beta$-carboline $\mathbf{8 b}$ got converted again into $\delta$-lactame $\mathbf{1 4 b}$ and $\gamma$-lactame $\mathbf{1 2 b}$ in comparable yields $(30 \%$ and $26 \%$, respectively). Since in 12b the $\eta^{5}-\mathrm{C}_{6} \mathrm{H}_{5} \mathrm{Fe}^{+}$fragment is situated in the endo position of decreased accessibility, this $\gamma$-lactame seems to resist the imidazole-mediated trans-annular ring opening finally leading to 13b. It must be pointed out here that - contrary to $9 \mathbf{b}$ and $9 \mathrm{~b} / \mathbf{i n v}-\mathbf{9 a}$ did not undergo an analogous transformation with the cleavage of the $\mathrm{C} 12 \mathrm{~b}-\mathrm{N} 5$ bond, which is probably facilitated by the electron withdrawing effect of the adjacent methoxycarbonyl group.

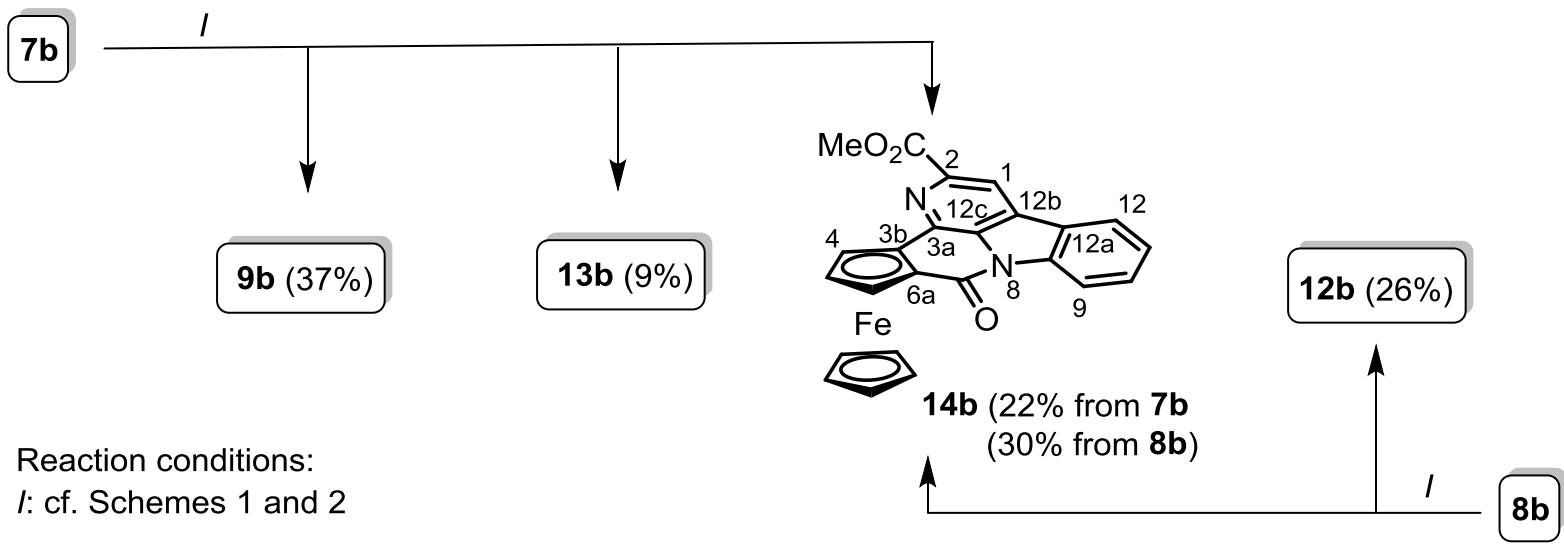

\section{Scheme 3.}

From the aspect of the stereochemical outcome of the tandem cyclizations of imines $\mathbf{6 a}, \mathbf{b}$, it must be pointed out that under the conditions promoting the primary activation of the carboxyl group, the formation of the isomers with " $R$ "-configuration at the $\mathrm{C} 12 \mathrm{~b}$ stereogenic center is preferred over that of the diastereomers with " $S$ "-configuration at the same stereogenic center irrespective of the helical chirality of ring $C$ (isolable yields: $58 \% / 24 \%$ for 12a/9a and $53 \% /(15 \%+5 \%$ ) for $\mathbf{1 2 b} /(\mathbf{9 b} / \mathbf{i n v}+\mathbf{9 b})$, respectively). On the basis of the results of the experiment conducted under forced conditions (cf. Method $K$ : Scheme 2) and supported by the modeling studies discussed below, it seems

Corresponding author: Tel.: +36 1372 2500/6591; Fax: +36 1372 2548; email:

csampai@chem.elte.hu 
that it is $\mathbf{9 b}$ /inv which is formed as the primary product in the tandem cyclization reaction of $\mathbf{6 b}$. In order to disclose the pathways of CDI-promoted tandem cyclization reactions accounting for this diastereoselectivity, we undertook comparative DFT modeling studies [51] carried out at B3LYP level of theory [52] with 6-31 G(d,p) basis set [53] on the cyclic $N$-acyliminium intermediates 15a and 15b supposed to be resulted from the cyclization of $\mathbf{6 a}, \mathbf{b}$, and stabilized by the highly electron-donor ferrocene residue.
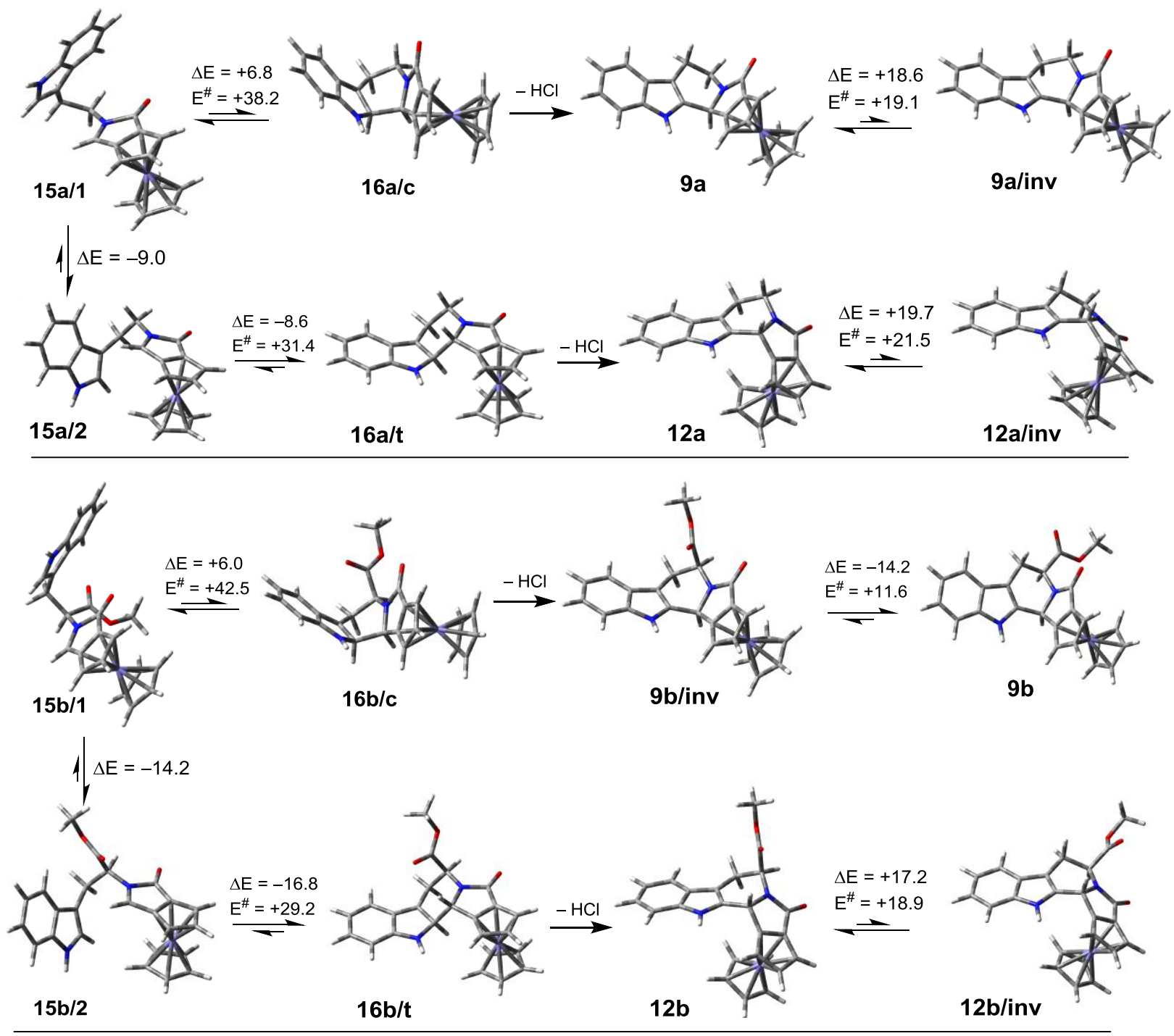

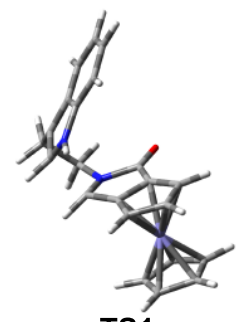

TS1 (from 15a/1 to $16 \mathrm{a} / \mathrm{c}$ )

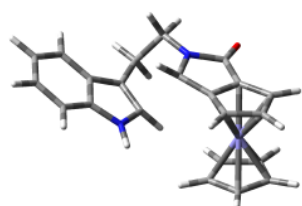

TS2

(from 15a/2 to $16 \mathrm{a} / \mathrm{t}$ )

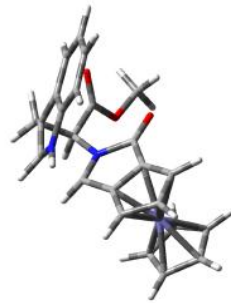

TS3

(from $15 \mathrm{~b} / 1$ to $16 \mathrm{~b} / \mathrm{c})$

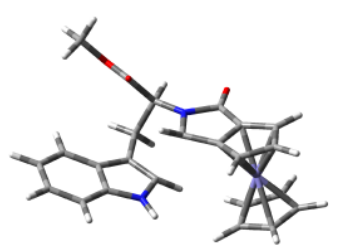

TS4

(from $15 \mathrm{~b} / 2$

to $16 \mathrm{~b} / \mathrm{t}$ )

Intermediates types15 and 16 as well as TS structures TS1-4 are cations with chloride as counterion (not presented for clarity)

Scheme 4 DFT representation of the interconversions of possible diastereomeric intermediates and lactame products involved in the CDI-mediated tandem cyclizations. The relative total electronic energy values and activation barriers $[\mathrm{kJ} / \mathrm{mol}]$ were calculated at B3LYP/6-31 $\mathrm{G}(\mathrm{d}, \mathrm{p})$ level of theory using IEFPCM to imitate the experimental conditions $\left(\varepsilon_{\mathrm{DMF}}=36.7\right)$.

Corresponding author: Tel.: +36 1372 2500/6591; Fax: +36 1372 2548; email:

csampai@chem.elte.hu 
The geometry optimization found conformers $\mathbf{1 5 a}, \mathbf{b} / \mathbf{1}$ and $\mathbf{1 5 a}, \mathbf{b} / \mathbf{2}$ (Scheme 4) as local minima on the potential energy surfaces (PES) preformed for the crucial bond formation between the $\mathrm{C} 12 \mathrm{a}$ and $\mathrm{C} 12 \mathrm{~b}$ atoms to yield intermediates $\mathbf{1 6} \mathbf{a}, \mathbf{b} / \mathbf{c}$ and $\mathbf{1 6}, \mathbf{b} / \mathbf{t}$ of which deprotonation finally leads to two types of diastereomeric products $\mathbf{9 a}, \mathbf{b}$ and 12a,b, respectively. Using QST2 method [54] the transition states of the crucial cyclization steps $15 / \mathbf{1} \rightarrow \mathbf{1 6} / \mathbf{c}$ and $\mathbf{1 5 / 2} \rightarrow \mathbf{1 6} / \mathbf{t}$ were identified on the PES as saddle points and confirmed by IRC analysis [55]. The total electron energy values for all optimized structures were recalculated with IEFPCM solvent model [56] employing the dielectric constant of DMF $(\varepsilon=36.7)$ to provide a more realistic representation of the experimental conditions. Finally, considering the $\Delta \mathrm{E}$ and $\Delta \mathrm{E}^{\#}$ values presented on Scheme 4 it can be stated that the results of modeling studies provide a satisfactory support for the proposed reaction pathways outlined above, as both the relative energetics of the relevant conformers of the primarily formed $\mathrm{N}$-acyliminium intermediates $(\mathbf{1 5 a}, \mathbf{b} / \mathbf{1}$ and $\mathbf{1 5 a}, \mathbf{b} / \mathbf{2})$ and the activation barriers of their ring closures, ultimately determining the relative configuration of the products, are in good agreement with the diastereoselectivity experienced in the CDI-mediated tandem cyclization reactions of imines $\mathbf{6 a}, \mathbf{b}$. On the other hand, the higher activation barriers of the ring closures of $\mathbf{1 5 a}, \mathbf{b} / \mathbf{1}(+38.2 \mathrm{~kJ} / \mathrm{mol}$ and $+42.5 \mathrm{~kJ} / \mathrm{mol})$ relative to those of $\mathbf{1 5 a}, \mathbf{b} / 2(+31.4 \mathrm{~kJ} / \mathrm{mol}$ and $+29.2 \mathrm{~kJ} / \mathrm{mol})$ seem to correlate with the opposite signs of the energetics calculated for these elementary steps $[\Delta \mathrm{E}(\mathbf{1 6 a} / \mathbf{c}-\mathbf{1 5 a} / \mathbf{1}) /(\mathbf{1 6 b} / \mathbf{c}-\mathbf{1 5 b} / \mathbf{1})=+6.8 \mathrm{~kJ} / \mathrm{mol} /+6.0 \mathrm{~kJ} / \mathrm{mol}, v s$. $\Delta \mathrm{E}(\mathbf{1 6 a} / \mathbf{t}-\mathbf{1 5 a} / \mathbf{2}) /(\mathbf{1 6} \mathbf{b} / \mathbf{t}-\mathbf{1 5 b} / \mathbf{2})=-8.6 \mathrm{~kJ} / \mathrm{mol} /-16.8 \mathrm{~kJ} / \mathrm{mol}]$. The total electron energy values of the possible conformer pairs of the lactame products and the activation barriers of their interconversions were also calculated by the aforementioned DFT method and solvent model (Scheme 4). Although the results indicate that - except for $\mathbf{9 b / i n v ~} \rightarrow \mathbf{9 b}$ - the ring inversions of the isolated lactames $9 \mathbf{a}$ and 12a,b are not favored processes in terms of relative energetics, due to their low activation barriers the presence of minimal amounts of conformers 9a/inv and 12a,b/inv $(<1 \%)$ cannot be ruled out in the appropriate reaction mixtures or in the dissolved samples subjected to NMR measurements. However, since the transition state was located with a fixed position of the methoxycarbonyl group, the calculated activation barrier for ring inversion $\mathbf{9 b} / \mathbf{i n v} \rightarrow \mathbf{9 b}(+11.6 \mathrm{~kJ} / \mathrm{mol})$ is certainly lower than the real one of which height must substantially be increased by the rotation of the bulky substituent which, sweeping through the plane of the lactame carbonyl group, strongly interferes with the skeletal atoms.

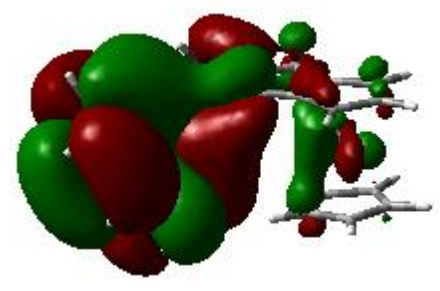

HOMO of $15 a / 2$ $\mathrm{E}=-8.51 \mathrm{eV}$

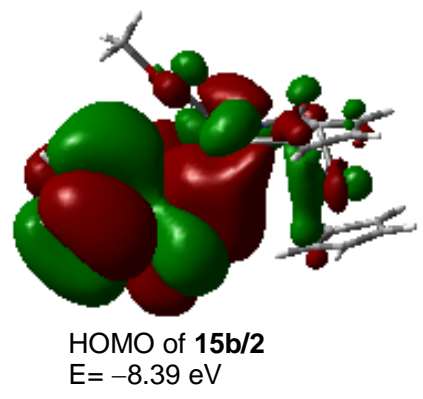

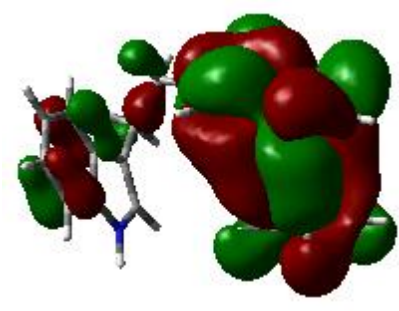

HOMO-2 of $15 \mathbf{a} / 2$ $\mathrm{E}=-9.57 \mathrm{eV}$

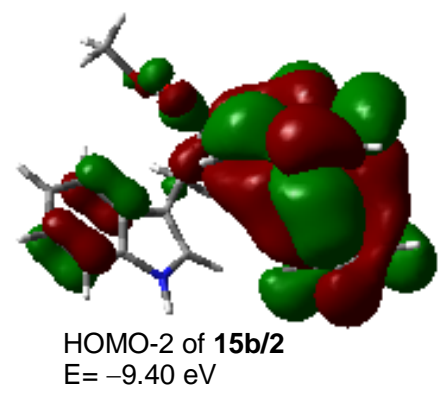

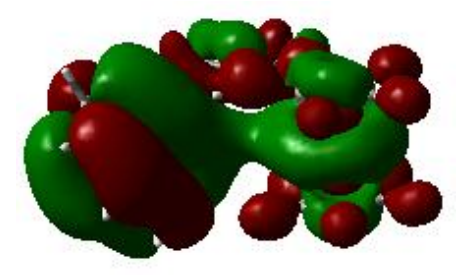

HOMO-5 of $15 \mathrm{a} / \mathbf{2}$ $\mathrm{E}=-10.39 \mathrm{eV}$

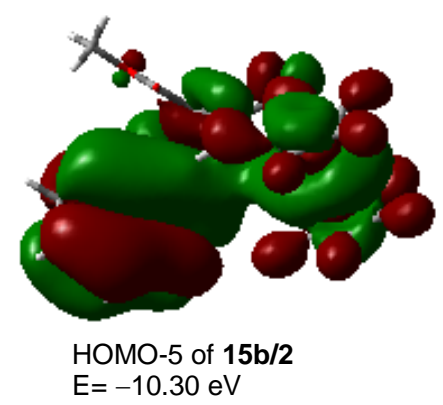

Figure 1 Selected bonding orbitals of conformers $15 \mathbf{a}, \mathbf{b} / \mathbf{2}$, the precursors of ring closures finally leading to lactames 12a,b, determined by B3LYP/6-31 G(d,p) analysis performed on optimized structures.

Corresponding author: Tel.: +36 1372 2500/6591; Fax: +36 1372 2548; email:

csampai@chem.elte.hu 
The relative energetics of the conformer pairs $15 a / 1-15 a / 2$ and $\mathbf{1 5 b} / \mathbf{1}-\mathbf{1 5} \mathbf{b} / \mathbf{2}$, respectively, preformed for the crucial cyclization steps responsible for the stereochemical outcome of the overal reactions, are also worth for discussion based on the analysis of relevant bonding orbitals (Figure 1). Accordingly, it might be concluded that the extra stabilization of conformers type 15/2 relative to that of alternative conformers type $\mathbf{1 5 / 1}$ can at least partially be attributed to the delocalization of HOMO-5 presenting a weak bonding between the iron center and the proximal indole ring. Iminium ions $\mathbf{1 5 a}, \mathbf{b} / \mathbf{2}$ are also stabilized by interactions of the cationic center with the donor indole and ferrocene moieties, as demonstrated by HOMO and HOMO-2, respectively.

\subsection{Structure determination of the novel compounds}

The spectroscopic data listed in the Experimental part are consistent with the structures of novel compounds 2a,b, 3a,b 4b, 6a,b, 7a,b, 8a,b, 9a,b, 9b/inv, 11, 12a,b, 13b and 14b, however the following points are necessary to be highlighted.

Due to the presence of incorporated ferrocene- and/or tryptophane fragments with fixed elements of chirality, the absolute configurations of $\mathbf{3 b}, \mathbf{4 b}, \mathbf{6 b}, \mathbf{7 a}, \mathbf{b}, \mathbf{8 a}, \mathbf{b}, \mathbf{9 a}, \mathbf{b}, \mathbf{9 b} / \mathbf{i n v}, \mathbf{1 2} \mathbf{a}, \mathbf{b}$ and 13b follow from their relative configurations.

The characteristic cross peaks resulted from the ${ }^{2} J$ - and ${ }^{3} J$ couplings between the signals of nucleus pairs H1/C4a, H1/C9a, H9/C4a and H9/C9a detected by ${ }^{1} \mathrm{H}^{13}{ }^{13} \mathrm{C}-\mathrm{HMBC}$ method for $\mathbf{3 a}, \mathbf{b} \mathbf{4 b}$, $\mathbf{7 a}, \mathbf{b}$ and $\mathbf{8 a}, \mathbf{b}$ indicate the presence of the $\beta$-carboline skeleton, i.e. the condensation of the tetrahydropyridine ring to the indole residue. In a similar way, the polycyclic constitution of $\mathbf{9 a}, \mathbf{b}$, 9b/inv and 12a,b is unequivocally proved by the cross peak correlations between the signals originated from atom pairs $\mathrm{H} 12 \mathrm{~b} / \mathrm{C} 7 \mathrm{a}, \mathrm{H} 12 \mathrm{~b} / \mathrm{C} 12 \mathrm{a}, \mathrm{H} 12 \mathrm{~b} / \mathrm{C} 4$ and $\mathrm{H} 6 / \mathrm{C} 4$ discernible in their ${ }^{1} \mathrm{H}^{-13} \mathrm{C}-$ HMBC spectra. In accord with their relative configuration, the NOESY spectra of $\mathbf{9 a}, \mathbf{9 b}$ and $\mathbf{9 b} / \mathbf{i n v}$ disclosed that $\mathrm{H} 12 \mathrm{~b}$ is situated in the proximity of the protons of the freely rotating $\eta^{5}-\mathrm{C}_{5} \mathrm{H}_{5}$ residue. In 9b and 9b/inv the " $S$ " configuration of the $C 6$ stereogenic center was evidenced by NOE's detected between protons $\mathrm{H} 12 \mathrm{~b}$ and $\mathrm{H}_{\mathrm{A}}$ being in relative 1,3-cis position on the ring system. On the other hand, in 12a and 12b the " $R$ " configuration of the $\mathrm{C} 12 \mathrm{~b}$ stereogenic center associated with the endo orientation of the $\eta^{5}-\mathrm{C}_{5} \mathrm{H}_{5}$ ring is evidenced by the NOE's generated by its interactions with $\mathrm{H}_{\mathrm{A}}$ and the indole NH proton, respectively. In keeping with the results of NOESY experiments, in the optimized structures of these compounds $\mathrm{H} 7_{\mathrm{A}}$, attached to ring $C$ with half chair conformation of " $P$ "helicity, is situated in endo-axial position in the proximity of the $\eta^{5}-\mathrm{C}_{5} \mathrm{H}_{5}$ ring. Being in the shielding region of the indole ring, ${ }^{1} \mathrm{H}$ resonances of this residue measured for 12a and 12b $(3.68$ and $3.70 \mathrm{ppm}$, resp.) are significantly upfield-shifted relative to those measured for diastereomers $\mathbf{9 a}, \mathbf{b}$ and $\mathbf{9 b} / \mathbf{i n v}$ carrying the $\eta^{5}-\mathrm{C}_{5} \mathrm{H}_{5}$ ring in exo site of the polycyclic skeleton (4.06-4.31 ppm). The NOESY experiments carried out for $\mathbf{9 a}, \mathbf{b}$ and $\mathbf{9 b} / \mathbf{i n v}$ detected an additional interaction between $\mathrm{H} 12 \mathrm{~b}$ and $\mathrm{H6}_{\mathrm{A}}$ atoms. Supporting the results of DFT modeling studies on 9a,b, the coupling patterns of H6- and H7 multiplets discernible in their ${ }^{1} \mathrm{H}-\mathrm{NMR}$ spectra refer to " $M$ " helical chirality of ring $C$ with a half chair conformation carrying $\mathrm{H}_{\mathrm{A}}$ and $\mathrm{H} 7_{\mathrm{B}}$ in relative 1,2-diaxial position $\left[\mathrm{J}\left(\mathrm{H} 6_{\mathrm{A}} / \mathrm{H} 7_{\mathrm{B}}\right)=11.6 \mathrm{~Hz}\right.$ and $11.8 \mathrm{~Hz}$ for $9 \mathbf{a}$ and $9 \mathbf{b}$, resp.]. On the other hand, the opposite helical chirality (" $P$ ") of ring $C$ in $9 \mathbf{b} / \mathbf{i n v}$ and $\mathbf{1 2 b}$, carrying the methoxycarbonyl group in axial position, is reflected from the simple broadened doublet split of the signal of the $\mathrm{H}_{\mathrm{A}}$ proton $(7.1 \mathrm{~Hz}$ and $7.5 \mathrm{~Hz}$, resp.) due to an interaction with the $\mathrm{H} 7_{\mathrm{A}}$ proton and a negligible coupling with the $\mathrm{H} 7_{\mathrm{B}}$ proton. In 12a the same conformation of ring $C$ associated with helical chirality " $P$ " is also evidenced by the coupling pattern of the signals originated from the skeletal protons, which indicates only a weak interaction characterized by $2.0 \mathrm{~Hz}$ between $\mathrm{H}_{\mathrm{A}}$ and $\mathrm{H} 7_{\mathrm{B}}$. In the ${ }^{1} \mathrm{H}-\mathrm{NMR}$ spectrum of 12a the assignments of $\mathrm{H}_{\mathrm{A}^{-}}$and $\mathrm{H} 6_{\mathrm{B}}$ signals were supported by a NOESY experiment disclosing a significant interaction between protons $\mathrm{H}_{\mathrm{B}}$ and $\mathrm{H} 12 \mathrm{~b}$. Accordingly, the signal of $\mathrm{H}_{\mathrm{B}}$ is significantly upfield-shifted relative to that of the equatorial $\mathrm{H}_{\mathrm{A}}$ positioned in the proximity of the lactame carbonyl group exerting a significant anisotropic deshielding effect on the latter resonance (3.54 ppm and $4.98 \mathrm{ppm}$, resp.). It must be pointed out that in the ${ }^{1} \mathrm{H}$-NMR spectrum of $9 \mathrm{a}$ the resonance due to equatorial proton $\mathrm{H6}_{\mathrm{B}},(5.18 \mathrm{ppm})$ situated nearly in the plane of the lactame carbonyl group, is significantly downfield shifted relatively to that measured for $\mathrm{H}_{\mathrm{A}}(3.79 \mathrm{ppm})$ in axial position.

Corresponding author: Tel.: +36 1372 2500/6591; Fax: +36 1372 2548; email:

csampai@chem.elte.hu 
In order to detect the particular conformers of the fused $\gamma$-lactames we attempted to register their ${ }^{1} \mathrm{H}$-NMR spectra at low temperature using $\mathrm{CD}_{2} \mathrm{Cl}_{2}$ as solvent, however these efforts failed due to severe solubility problems. Instead, the almost exclusive presence of the preferred conformers of $\mathbf{9 a}$, and 12a,b was supported by comparative NMR-GIAO calculations [57] carried out for the optimized structures of the corresponding conformer pairs (Table 1) by B3LYP functional using the extended 6$311++\mathrm{G}(2 \mathrm{~d}, \mathrm{p})$ basis set [58]. Although no exact data can be given for the ratio of the particular components involved in the possible equilibrium ring inversion processes, in each studied case the difference between the calculated- and experimental chemical shifts and separation of the skeletal H6 signals (cf. 9a-9a/inv and 12a-12a/inv) unambiguously refer to a strong dominance of the diastereomer supposed to be detected by NMR experiments over its counterparts with reversed helicity of ring $C$. Supporting this view, the highly diagnostic vicinal coupling constants $J\left(\mathrm{H}_{\mathrm{A}} / \mathrm{H} 7_{\mathrm{B}}\right)$ and $J\left(\mathrm{H}_{\mathrm{A}} / \mathrm{H} 7_{\mathrm{A}}\right)$ are in good accord with the values calculated by a particular version of Karplus-equation using a parameter set composed for a general $\mathrm{N}-\mathrm{CH}_{2}-\mathrm{CH}_{2}-\mathrm{C}$ sequence [59] and the dihedral angles found in the modeled structures of the isolated $\gamma$-lactames (Table 1). It is also important to note here that the substantial dismatch between the calculated and measured values of $J\left(\mathrm{H} 6_{\mathrm{A}} / \mathrm{H} 7_{\mathrm{B}}\right)$ rules out the presence of diastereomers 9a/inv, 12a/inv and 12b/inv in significant amounts in the solutions subjected to NMR studies. Finally, the alternative conformations of ring $C$ with opposite helicity in diastereomers $9 \mathrm{~b}$ and $\mathbf{9 b} / \mathbf{i n v}$ are conclusively evidenced by the highly similar calculated- and experimental NMR parameter pairs listed in Table 1. This stereochemical relation was also confirmed by ring inversion $\mathbf{9 b} / \mathbf{i n v} \rightarrow \mathbf{9 b}$ carried out in a separate experiment under the conditions of Method $K$, as discussed above.

The relative configurations of carboxyferrocenyl-substituted $\beta$-carbolines $\mathbf{7 a}, \mathbf{b}$ and $\mathbf{8 a}, \mathbf{b}$, the precursors of CDI-mediated cyclization reactions assumed to take place with the preservation of the configuration of the particular stereogenic centers, were deduced from those determined for the corresponding lactame products types $\mathbf{9}$ and $\mathbf{1 2}$.

In compound 13b the constitution and the bent conformation of the nine-membered azonine ring with " $E$ " lactame residue were established on the basis of NOESY cross-peak correlations between proton pairs $\mathrm{H} 3 / \mathrm{H}_{\mathrm{A}}, \mathrm{H} 5 / \mathrm{H} 7_{\mathrm{B}}, \mathrm{H} 7_{\mathrm{B}} / \mathrm{H} 8, \mathrm{H} 12 / \mathrm{H} 13$ and $\mathrm{H} 1 / \mathrm{H} 13$.

The significant downfield shift of the H9 signal in the ${ }^{1} \mathrm{H}-\mathrm{NMR}$ spectrum of $\mathbf{1 4 b}(8.62 \mathrm{ppm})$ refers to the proximity of the oxygen atom of the carbonyl group incorporated in the $\delta$-lactame ring fused to the ferrocene moiety. The broadened doublet signals due to $\mathrm{H} 9$ and $\mathrm{H} 12$ were unambiguously assigned on the basis of a NOESY interaction detected between proton pair H1/H12 being in spatial proximity on the rigid ring system.

Table 1: ${ }^{1} \mathrm{H}-\mathrm{NMR}$ shifts and separation of $\mathrm{H}_{\mathrm{A}}$ and $\mathrm{H} 6_{\mathrm{B}}$ signals calculated for diastereomer pairs $9 \mathbf{9 a - 9 a / i n v , ~ 9 b - 9 b / i n v , ~ 1 2 a - ~}$ 12a/inv and 12b-12b/inv (rows 1-6, reference: TMS) ${ }^{\mathrm{a}}$, dihedral angles between skeletal protons ( $\vartheta$ : rows 7 and 10) ${ }^{\mathrm{b}}$ and vicinal coupling constants $J\left(\mathrm{H}_{\mathrm{A}} / \mathrm{H} 7_{\mathrm{B}}\right)$ and $J\left(\mathrm{H}_{\mathrm{A}} / \mathrm{H} 7_{\mathrm{A}}\right)$ (calculated values: rows 8 and 11, measured values: rows 9 and 12$)$.

\begin{tabular}{|c|c|c|c|c|c|c|c|c|}
\hline & $9 \mathbf{a}$ & 9a/inv & $9 \mathbf{b}$ & 9b/inv & $12 a$ & 12a/inv & $12 \mathrm{~b}$ & 12b/inv \\
\hline 1. $\delta \mathrm{H}_{\mathrm{A}}[\mathrm{ppm}]$ (calcd.) & $3.84^{\mathrm{c}}$ & 3.47 & 4.18 & 5.28 & $5.00^{\mathrm{c}}$ & 3.68 & $5.85^{\mathrm{c}}$ & 4.84 \\
\hline 2. $\delta \mathrm{H} 6_{\mathrm{A}}[\mathrm{ppm}]$ (meas.) & \multicolumn{2}{|c|}{$3.79^{c}$} & 4.26 & 5.49 & \multicolumn{2}{|c|}{$4.98^{\mathrm{c}}$} & \multicolumn{2}{|c|}{$5.66^{\mathrm{c}}$} \\
\hline 3. $\delta \mathrm{H} 6_{\mathrm{B}}[\mathrm{ppm}]$ (calcd.) & $4.88^{\mathrm{c}}$ & 4.01 & - & - & $3.24^{\mathrm{c}}$ & 4.02 & - & - \\
\hline 4. $\delta \mathrm{H6} 6_{\mathrm{B}}[\mathrm{ppm}]$ (meas.) & \multicolumn{2}{|c|}{$5.18^{\mathrm{c}}$} & - & - & \multicolumn{2}{|c|}{$3.54^{\mathrm{c}}$} & - & - \\
\hline 5. $\Delta\left(\delta \mathrm{H6}_{\mathrm{A}}-\delta \mathrm{H6}_{\mathrm{B}}\right)[\mathrm{ppm}]$ (calcd.) & $-1.04^{\mathrm{c}}$ & -0.54 & - & - & $1.96^{\mathrm{c}}$ & -0.34 & - & - \\
\hline 6. $\Delta\left(\delta \mathrm{H}_{\mathrm{A}}-\delta \mathrm{H} 6_{\mathrm{B}}\right)[\mathrm{ppm}]$ (meas.) & \multicolumn{2}{|c|}{$-1.39^{c}$} & - & - & \multicolumn{2}{|c|}{$1.76^{\mathrm{c}}$} & - & - \\
\hline 7. $\vartheta\left(\mathrm{H} 6_{\mathrm{A}} / \mathrm{H} 7_{\mathrm{B}}\right)\left[{ }^{\circ}\right]$ (calcd.) & 162.8 & 79.1 & 167.7 & 73.6 & 74.9 & 157.2 & 77.7 & 150.5 \\
\hline 8. $J\left(\mathrm{H} 6_{\mathrm{A}} / \mathrm{H} 7_{\mathrm{B}}\right)[\mathrm{Hz}]\left(\right.$ calcd. $^{\mathrm{d}}$ & $10.9^{c}$ & 1.5 & 11.4 & 1.9 & $1.8^{c}$ & 10.1 & $1.6^{c}$ & 9.1 \\
\hline 9. $J\left(\mathrm{H} 6_{\mathrm{A}} / \mathrm{H} 7_{\mathrm{B}}\right)[\mathrm{Hz}]$ (meas.) & \multicolumn{2}{|c|}{$11.6^{\mathrm{c}}$} & 11.8 & $\sim 0$ & \multicolumn{2}{|c|}{$2.0^{\mathrm{c}}$} & \multicolumn{2}{|c|}{$\sim 0^{\mathrm{c}}$} \\
\hline 10. $\vartheta\left(\mathrm{H} 6_{\mathrm{A}} / \mathrm{H} 7_{\mathrm{A}}\right)\left[^{\circ}\right]$ (calcd.) & 44.8 & 35.8 & 51.9 & 39.8 & 42.0 & 41.2 & 35.4 & 38.1 \\
\hline 11. $J\left(\mathrm{H} 6_{\mathrm{A}} / \mathrm{H} 7_{\mathrm{A}}\right)[\mathrm{Hz}](\text { calcd. })^{\mathrm{d}}$ & $5.9^{c}$ & 7.3 & 4.8 & 6.8 & $6.4^{c}$ & 6.5 & $7.4^{c}$ & 7.0 \\
\hline 12. $J\left(\mathrm{H} 6_{\mathrm{A}} / \mathrm{H} 7_{\mathrm{A}}\right)[\mathrm{Hz}]$ (meas.) & \multicolumn{2}{|c|}{5.} & 4.3 & 7.1 & \multicolumn{2}{|c|}{$5.4^{c}$} & \multicolumn{2}{|c|}{$7.5^{c}$} \\
\hline
\end{tabular}

a. The calculations were performed by B3LYP/NMR-GIAO method using the extended 6-311 ++G(2d,p) basis set.

b. The values are extracted from the structures optimized by B3LYP functional employing 6-31 G(d,p) basis set.

c. The better match between the calculated and measured values is highlighted by bold-italic fonts.

d. Obtained by Karplus equation using $\vartheta$ values and a parameter set composed for a general $\mathrm{N}-\mathrm{CH}_{2}-\mathrm{CH}_{2}-\mathrm{C}$ sequence.

Corresponding author: Tel.: +36 1372 2500/6591; Fax: +36 1372 2548; email: csampai@chem.elte.hu 


\section{Conclusion}

By means of sequential use of Pictet-Spengler and $N$-acylation protocols 4-oxo-6,7,12,12btetrahydro- $4 H$-ferroceno[1,2]indolizino[8,7- $b]$ indoles, the first representatives of a novel $\beta$-carbolinebased alkaloid-like ring system incorporating fused metallocene and $\gamma$-lactame moieties were prepared as single enantiomers with the elements of planar- and central chirality. The conformation and the relative configuration of these products were determined by combined use of one- and twodimensional versions of ${ }^{1} \mathrm{H}$ - and ${ }^{13} \mathrm{C}-\mathrm{NMR}$ methods supported by theoretical NMR calculations. Besides the targeted $\gamma$-lactame products the ring closures of carboxyferrocenyl-substituted $\beta$ carbolines carrying methoxycarbonyl group in position 3 also afforded the planar chiral $\delta$-lactame $\left(S_{\mathrm{p}}\right)^{-}$methyl 7-oxo-7H-ferroceno[c]indolo[3,2,1-ij][1,5]naphthyridine-2-carboxylate of which formation was prevented by implementing an alternative method for the construction of the desired $\gamma$ lactames based on CDI-mediated tandem cyclization of simple carboxyferrocenyl-substituted tryptamine/tryptophane-derived imines. Possible reaction pathways accounting for the diastereoselectivity of the overall processes were proposed on the basis of the results obtained by comparative DFT modeling studies. Employing further imine precursors suitable to form a five- or six-membered cyclic $\mathrm{N}$-acyliminium intermediate capable of acting as efficient electrophilic component in intramolecular Pictet-Spengler reaction, this one-pot procedure may allow the facile synthesis of a range of related polyheterocyclic alkaloid analogues of potential biological interest. The evidenced propensity of metallocene-fused lactame products to undergo trans-anullar ring opening, taking place with simultaneous decomposition of the organometallic fragment, can be utilized in design of improved protocols to provide a relatively easy access to novel classes of medium-size heterocyclic scaffolds.

\section{Experimental}

All chemicals were obtained from commercially available sources (Aldrich, Fluka) and used without further purification. Melting points (uncorrected) were determined with a Boethius microstage. Merck Kieselgel (230-400 mesh, $60 \AA$ ) was used for flash column chromatography. The $R_{\mathrm{f}}$ values given for the separated products were determined using DCM-MeOH (20:1) as eluent on silica plate. The IR spectra were run by ATR (Attenuated Total Reflectance) method [60] on a Bruker IFS-55 FT-spectrometer controlled by Opus 3.0 software. Optical rotations were measured with a Zeiss Polamat A polarimeter. The ${ }^{1} \mathrm{H}$ - and ${ }^{13} \mathrm{C}-\mathrm{NMR}$ spectra were recorded in DMSO- $d_{6}$ or $\mathrm{CDCl}_{3}$ solution in $5 \mathrm{~mm}$ tubes at RT, on a Bruker DRX-500 spectrometer at 500 $\left({ }^{1} \mathrm{H}\right)$ and $125\left({ }^{13} \mathrm{C}\right) \mathrm{MHz}$, with the deuterium signal of the solvent as the lock and TMS as internal standard $\left({ }^{1} \mathrm{H}\right.$, $\left.{ }^{13} \mathrm{C}\right)$ The 2D-COSY, HSQC, HMBC and NOESY spectra were obtained by using the standard Bruker pulse programs. All calculations were carried out with the Gaussian 09 suite of programs [61]. Optimized structures are available from the authors.

\subsection{Preparation of imines $2 \boldsymbol{a}$ and $\boldsymbol{6} \boldsymbol{a}($ Method $A)$}

Tryptamine $(3.204 \mathrm{~g}, 20 \mathrm{mmol})$ and formylferrocene $(4.281 \mathrm{~g}, 20 \mathrm{mmol})$ or $\left(S_{\mathrm{p}}\right)$-2-formyl-ferrocene carboxylic acid $(5.161 \mathrm{~g}, 20 \mathrm{mmol})$ were heated in $\mathrm{MeOH}(20 \mathrm{~mL})$ at reflux temperature for $1 \mathrm{~h}$. The reaction mixture was evaporated to half of its volume and diluted with water $(30 \mathrm{~mL})$. The precipitated solid was filtered off, washed with a cold mixture of $\mathrm{MeOH}$-water (2:3) and dried to obtain the appropriate imine 2a or $\mathbf{6 a}$. Analytical samples of the products were recrystallized from mixtures of DCM-hexane.

\subsection{1. (E)-N-(2-(1H-Indol-3-yl)ethyl)-1-ferrocenylmethanimine (2a)}

Dark yellow solid. Yield: $5.840 \mathrm{~g}(82 \%)$; mp.: $67-70{ }^{\circ} \mathrm{C}$; IR $\left(\mathrm{cm}^{-1}\right): \sim 3300-2900,1643,1446,1245$, $1105,1043,1021,810,737 .{ }^{1} \mathrm{H}$ NMR $\left(\mathrm{CDCl}_{3}\right): 8.30(\mathrm{~s}, 1 \mathrm{H}, \mathrm{N} \underline{\mathrm{H}}) ; 8.03(\mathrm{~s}, 1 \mathrm{H}, \mathrm{CH}=\mathrm{H}) ; 7.72(\mathrm{~d}, J=7.4 \mathrm{~Hz}, 1 \mathrm{H}$, H4); 7.36 (d, $J=7.4 \mathrm{~Hz}, 1 \mathrm{H}, \mathrm{H} 7) ; 7.21(\mathrm{t}, J=7.4 \mathrm{~Hz}, 1 \mathrm{H}, \mathrm{H} 5) ; 7.17$ (t, $J=7.4 \mathrm{~Hz}, 1 \mathrm{H}, \mathrm{H6}) ; 7.05$ (br s, 1H, H2); 4.64 (t, $\left.J=1.8 \mathrm{~Hz}, 2 \mathrm{H}, \mathrm{H} 2^{\prime}, 5^{\prime}\right) ; 4.37$ (t, $\left.J=1.8 \mathrm{~Hz}, 2 \mathrm{H}, \mathrm{H}^{\prime}, 4^{\prime}\right) ; 4.06$ (s, $\left.5 \mathrm{H}, \eta^{5}-\mathrm{C}_{5} \underline{H}_{5}\right) ; 3.84$ (t, $J=6.8 \mathrm{~Hz}, 2 \mathrm{H}, \mathrm{N}-$ $\left.\mathrm{C}_{2}\right) ; 3.17\left(\mathrm{t}, J=6.8 \mathrm{~Hz}, 2 \mathrm{H}, \mathrm{C}-\mathrm{C}_{2}\right) ;{ }^{13} \mathrm{C}$ NMR $\left(\mathrm{CDCl}_{3}\right): 162.0(\underline{\mathrm{CH}}=\mathrm{N}) ; 136.8(\mathrm{C} 7 \mathrm{a}) ; 128.0(\mathrm{C} 3 \mathrm{a}) ; 122.6(\mathrm{C} 2)$; 122.3 (C6); 119.6 (C5); 119.4 (C4); 114.4 (C3); 111.7 (C7); 80.5 (C1'); 71.0 (C3',4'); $69.5\left(\eta^{5}-\underline{C}_{5} \mathrm{H}_{5}\right) ; 69.0$ $\left(\mathrm{C} 2^{\prime}, 5^{\prime}\right) ; 62.3\left(\mathrm{~N}-\mathrm{CH}_{2}\right) ; 27.3\left(\mathrm{C}^{-} \mathrm{CH}_{2}\right)$; Anal. Calcd. for $\mathrm{C}_{21} \mathrm{H}_{20} \mathrm{FeN}_{2}$ (356.25): C, 70.80; H, 5.66; N, 7.86. Found: C: $70.70 ; \mathrm{H}: 5.74 ; \mathrm{N}, 7.91 \%$.

Corresponding author: Tel.: +36 1372 2500/6591; Fax: +36 1372 2548; email: csampai@chem.elte.hu 


\subsection{2. $\left(S_{p}, E\right)-2-(((2-(1 H-I n d o l-3-y l)$ ethyl)imino $)$ methyl $)$ ferrocene carboxylic acid $(\boldsymbol{6} \boldsymbol{a})$}

Dark red solid. Yield: $6.084 \mathrm{~g}(76 \%)$; mp.: $85-87{ }^{\circ} \mathrm{C}$; $[\alpha]_{\mathrm{D}}^{25}:+42.2^{\circ}(\mathrm{EtOH} c=0.084 \mathrm{~g} / 100 \mathrm{~mL})$; IR $\left(\mathrm{cm}^{-1}\right): \sim 3600-2700,1710,1645,1585,1437,1340,1230,1106,1003,821,741 .{ }^{1} \mathrm{H}$ NMR (DMSO- $\left.d_{6}\right): 10.91(\mathrm{~s}$, $1 \mathrm{H}, \mathrm{N} \underline{\mathrm{H}}) ; 8.49(\mathrm{~s}, 1 \mathrm{H}, \mathrm{CH}=\mathrm{N}) ; 7.63(\mathrm{~d}, J=7.3 \mathrm{~Hz}, 1 \mathrm{H}, \mathrm{H} 4) ; 7.33(\mathrm{~d}, J=7.3 \mathrm{~Hz}, 1 \mathrm{H}, \mathrm{H} 7) ; 7.07$ (t, J=7.3 Hz, 1H, H6); 7.01 (t, J=7.3 Hz, 1H, H5); 7.23 (br s, 1H, H2); 5.11 (br s, 1H, H5'); 4.82 (br s, 1H, H3'); 4.70 (t, J=1.8 Hz, $\left.1 \mathrm{H}, \mathrm{H} 3^{\prime}\right) ; 4.05$ (s, $\left.5 \mathrm{H}, \eta^{5}-\mathrm{C}_{5} \underline{\mathrm{H}}_{5}\right) ; 3.90\left(\mathrm{t}, J=6.4 \mathrm{~Hz}, 2 \mathrm{H}, \mathrm{N}-\mathrm{C}_{2}\right)$; 3.10 (t, J=6.4 Hz, 2H, C-C $\left.\underline{\mathrm{H}}_{2}\right)$; due to exchange processes the signal of $\mathrm{CO}_{2} \mathrm{H}$ proton could not be detected in the spectrum; ${ }^{13} \mathrm{C}$ NMR (DMSO-d $\left.d_{6}\right): 171.5\left(\mathrm{CO}_{2} \mathrm{H}\right)$ $167.5(\underline{\mathrm{CH}=\mathrm{N})} ; 137.2(\mathrm{C} 7 \mathrm{a}) ; 127.9(\mathrm{C} 3 \mathrm{a}) ; 124.0(\mathrm{C} 2) ; 121.9(\mathrm{C} 6) ; 119.3$ (two coalesced lines, $\mathrm{C} 4$ and $\mathrm{C} 5) ; 112.3$ (C7); 112.0 (C3); 76.4 (C5'); 75.9 (C1'); 75.5 (C4'); 73.6 (C3'); $71.9\left(\eta^{5}-\underline{C}_{5} \mathrm{H}_{5}\right) ; 70.2\left(\mathrm{C}^{\prime}\right.$ '); $57.8\left(\mathrm{~N}^{\prime} \underline{\mathrm{CH}}_{2}\right) ; 26.5$ $\left(\mathrm{C}-\mathrm{CH}_{2}\right)$; Anal. Calcd. for $\mathrm{C}_{22} \mathrm{H}_{20} \mathrm{FeN}_{2} \mathrm{O}_{2}$ (400.26): C, 66.02; H, 5.04; N, 7.00;. Found: C: 65.94; H: 5.12; N, $7.08 \%$.

\subsection{Preparation of imines $2 \boldsymbol{b}$ and $\boldsymbol{6} \boldsymbol{b}($ Method $B)$}

A mixture of $(L)$-tryptophane methylester hydrochloride $(5.094 \mathrm{~g}, 20 \mathrm{mmol}), \mathrm{Na}_{2} \mathrm{CO}_{3},(2.650 \mathrm{~g}, 25$ mmol), water $(40 \mathrm{~mL})$ and DCM $(80 \mathrm{~mL})$ was intensively stirred for ca. $5 \mathrm{~min}$., the phases were separated. The aqueous solution was extracted with DCM $(3 \times 30 \mathrm{~mL})$. To the combined organic phase formylferrocene $(4.281 \mathrm{~g}$, $20 \mathrm{mmol})$ or $\left(S_{\mathrm{p}}\right)$-2-formyl-ferrocene carboxylic acid $(5.161 \mathrm{~g}, 20 \mathrm{mmol})$ was added. The solution was dried on $\mathrm{Na}_{2} \mathrm{SO}_{4}$ then evaporated to dryness to obtain a solid residue which was trituated with cold $\mathrm{MeOH}$, filtered off washed thoroughly with water and dried. Analytical samples of the products were recrystallized from mixtures of DCM-hexane.

\subsubsection{Methyl (S,E)-2-(ferrocenylmethyleneamino)-3-(1H-indol-3-yl)propanoate (2b)}

Dark yellow solid. Yield: $7.883 \mathrm{~g}(93 \%)$; $\mathrm{mp}: 78-81^{\circ} \mathrm{C} ;[\alpha]_{\mathrm{D}}{ }^{25}:-57.5^{\circ}(\mathrm{EtOH} c=0.053 \mathrm{~g} / 100 \mathrm{~mL})$; IR $\left(\mathrm{cm}^{-1}\right):$ 3600-2700, 1742, 1600, 1580, 1437, 1340, 1244, 1100, 1012, 833, 746. ${ }^{1} \mathrm{H}$ NMR (DMSO- $\left.d_{6}\right): 10.82(\mathrm{~s}$, $1 \mathrm{H}, \mathrm{N} \underline{\mathrm{H}}$, indole); $8.36(\mathrm{~s}, 1 \mathrm{H}, \mathrm{C} \underline{\mathrm{H}}=\mathrm{N}) ; 7.61(\mathrm{~d}, J=7.6 \mathrm{~Hz}, 1 \mathrm{H}, \mathrm{H} 4) ; 7.30$ (d, J=7.6 Hz, 1H, H7); 7.08 (t, J=7.6 Hz, 1H, H6); 6.96 (t, J=7.6 Hz, 1H, H5); 7.09 (br s, 1H, H2); 4.74 (t, J=18.0 Hz, 2H, H2',5'); 4.40 (t, J=1.8 Hz, 2H, H3',4'); 4.51 (dd, $J=9.4$ and $4.4 \mathrm{~Hz}, \mathrm{H}, \mathrm{N}-\mathrm{CH}) ; 4.10$ (s, 5H, $\left.\eta^{5}-\mathrm{C}_{5} \underline{\mathrm{H}}_{5}\right) ; 3.76$ (s, 3H, $\left.\mathrm{CO}_{2} \underline{\mathrm{H}}_{3}\right), 3.45$ (dd, $J=14.7$ and $\left.4.4 \mathrm{~Hz}, 1 \mathrm{H}, \mathrm{C}-\underline{\mathrm{C}}_{\mathrm{A}} \mathrm{H}_{\mathrm{B}}\right) ; 3.22\left(\mathrm{dd}, J=14.7\right.$ and $\left.9.7 \mathrm{~Hz}, 1 \mathrm{H}, \mathrm{C}-\mathrm{CH}_{\mathrm{A}} \underline{\mathrm{H}}_{\mathrm{B}}\right) ;{ }^{13} \mathrm{C} \mathrm{NMR}$ (DMSO-d $\left.d_{6}\right): 171.8$ $\left(\underline{C O}_{2} \mathrm{CH}_{3}\right) ; 161.2(\underline{\mathrm{CH}}=\mathrm{N}) ; 136.4(\mathrm{C} 7 \mathrm{a}) ; 127.4(\mathrm{C} 3 \mathrm{a}) ; 124.1(\mathrm{C} 2) ; 121.5(\mathrm{C} 6) ; 119.0(\mathrm{C} 5) ; 118.6$ (C4), 112.5 (C7); 110.0 (C3); 80.1 (C1'); $71.0\left(\mathrm{C}^{\prime}, 4^{\prime}\right) ; 69.2\left(\eta^{5}-\underline{\mathrm{C}}_{5} \mathrm{H}_{5}\right) ; 68.3\left(\mathrm{C} 2^{\prime}, 5^{\prime}\right) ; 71.2(\mathrm{~N}-\underline{\mathrm{CH}}) ; 53.6\left(\mathrm{CO}_{2} \mathrm{CH}_{3}\right) ; 29.1$ $\left(\mathrm{C}-\mathrm{CH}_{2}\right)$; Anal. Calcd. for $\mathrm{C}_{23} \mathrm{H}_{22} \mathrm{FeN}_{2} \mathrm{O}_{2}$ (414.29): C, 66.68; H, 5.35; N, 6.76;. Found: C: 66.85; H: 5.41; N, $6.65 \%$.

\subsection{2. ( $\left.S_{p}, S, E\right)-2-(((1-M e t h o x y c a r b o n y l-2-(1 H$-indol-3-yl)ethyl)imino $)$ methyl)ferrocene carboxylic acid $(\boldsymbol{6} \boldsymbol{b})$}

Dark red solid. Yield: $7.883 \mathrm{~g}(86 \%)$; mp.: $114-117^{\circ} \mathrm{C} ;[\alpha]_{\mathrm{D}}{ }^{25}:-23.9^{\circ}\left(\mathrm{CHCl}_{3} c=0.071 \mathrm{~g} / 100 \mathrm{~mL}\right)$; IR $\left(\mathrm{cm}^{-1}\right):$ 3600-2800, 1735, 1690, 1640, 1570, 1458, 1443, 1369, 1254, 1106, 1005, 823, 742. ${ }^{1} \mathrm{H}$ NMR (DMSO$\left.d_{6}\right): 10.89(\mathrm{~s}, 1 \mathrm{H}, \mathrm{N} \underline{\mathrm{H}}) ; 8.43(\mathrm{~s}, 1 \mathrm{H}, \mathrm{C} \underline{\mathrm{H}}=\mathrm{N}) ; 7.56(\mathrm{~d}, J=7.3 \mathrm{~Hz}, 1 \mathrm{H}, \mathrm{H} 4) ; 7.32$ (d, J=7.3 Hz, 1H, H7); 7.06 (t, $J=7.3 \mathrm{~Hz}, 1 \mathrm{H}, \mathrm{H6}$ ); 6.99 (t, J=7.3 Hz, 1H, H5); 7.15 (d, J=1.8 Hz, 1H, H2); 5.07 (br s, 1H, H5'); 4.83 (br s, $1 \mathrm{H}$, H3'); 4.70 (t, $\left.J=2.0 \mathrm{~Hz}, 1 \mathrm{H}, \mathrm{H} 4^{\prime}\right) ; 4.49$ (dd, J=8.9 and $\left.4.6 \mathrm{~Hz}, \mathrm{H}, \mathrm{N}-\mathrm{CH}\right) ; 4.13$ (s, 5H, $\eta^{5}-\mathrm{C}_{5} \mathrm{H}_{5}$ ); 3.72 (s, $3 \mathrm{H}$, $\mathrm{CO}_{2} \underline{\mathrm{CH}}_{3}$ ), 3.38 (dd, $J=14.5$ and $4.6 \mathrm{~Hz}, 1 \mathrm{H}, \mathrm{C}-\underline{\mathrm{C}}_{\mathrm{A}} \mathrm{H}_{\mathrm{B}}$, partly overlapped by the HDO signal of the solvent); 3.19 (dd, $J=14.5$ and $8.9 \mathrm{~Hz}, 1 \mathrm{H}, \mathrm{C}-\mathrm{CH}_{\mathrm{A}} \mathrm{H}_{\mathrm{B}}$ ) due to exchange processes the signal of $\mathrm{CO}_{2} \mathrm{H}$ proton could not be detected in the spectrum; ${ }^{13} \mathrm{C}$ NMR $\left(\mathrm{DMSO}-d_{6}\right): 171.4\left(\underline{\mathrm{CO}_{2}} \mathrm{H}\right) ; 171.0\left(\underline{\mathrm{CO}}_{2} \mathrm{CH}_{3}\right) ; 167.5(\underline{\mathrm{CH}}=\mathrm{N}) ; 136.6(\mathrm{C} 7 \mathrm{a})$; 127.3 (C3a); 124.5 (C2); 121.5 (C6); 119.1 (C5);118.7 (C4), 112.1 (C7); 109.5 (C3); 76.5 (C5'); 75.5 (C3'); 73.5 (C4'); $73.2\left(\mathrm{C}^{\prime}\right) ; 71.9\left(\eta^{5}-\underline{\mathrm{C}}_{5} \mathrm{H}_{5}\right) ; 70.2\left(\mathrm{C}^{\prime}\right.$ '); $70.7(\mathrm{~N}-\underline{\mathrm{CH}}) ; 53.2\left(\mathrm{CO}_{2} \underline{\mathrm{CH}}_{3}\right) ; 28.6\left(\mathrm{C}-\underline{\mathrm{CH}_{2}}\right)$; Anal. Calcd. for $\mathrm{C}_{24} \mathrm{H}_{22} \mathrm{FeN}_{2} \mathrm{O}_{4}$ (458.30): C, 62.90; H, 4.84; N, 6.11. Found: C: 63.04; H: 4.77; N, 6.20\%.

\subsection{Pictet-Spengler cyclizations of imine $2 a$ by Methods $C$-G: synthesis of 1-ferrocenyl-2,3,4,9-tetrahydro-1H- pyrido[3,4-b]indole $(3 a)$}

Imine 2a (3.563 g, $10 \mathrm{mmol})$ was added to the corresponding acidic mixture ((Method $C: 70 \%$ $\mathrm{HClO}_{4} / \mathrm{EtOH}(1 \mathrm{~mL} / 15 \mathrm{~mL})$; Method $D: 70 \% \mathrm{HClO}_{4} / \mathrm{AcOH}(1 \mathrm{~mL} / 15 \mathrm{~mL})$; Method $E$ : TFA/AcOH $(1 \mathrm{~mL} / 15$ $\mathrm{mL})$; Method $F: \mathrm{H}_{3} \mathrm{BO}_{3} / \mathrm{AcOH}(0.350 \mathrm{~g} / 15 \mathrm{~mL})$; Method $G$ : AcOH $\left.(15 \mathrm{~mL})\right)$ The resulted solution was stirred and heated at reflux (for $24 \mathrm{~h}$ by Methods $C$ and $G$ and for 4 h by Methods $D-F$ ) under argon and evaporated to dryness. The residue was triturated with water and the $\mathrm{pH}$ of the resulted suspension was adjusted to 8-9 by addition of solid $\mathrm{Na}_{2} \mathrm{CO}_{3}$ in small portions. The solid precipitate was collected by filtration, washed with cold $\mathrm{EtOH}$ and dried to obtain 3a. An analytical sample was recrystallized from EtOH. Yield: $1.283 \mathrm{~g}$ (36\% by Method $C) ; 0.891 \mathrm{~g} \mathrm{(25 \%} \mathrm{by} \mathrm{Method} D) ; 1.603 \mathrm{~g} \mathrm{(45 \%} \mathrm{by} \mathrm{Method} E) ; 1.960 \mathrm{~g}(55 \%$ by Method $F) ; 2.850 \mathrm{~g}$ $(80 \%$ by Method $G)$; mp.: $98-100{ }^{\circ} \mathrm{C} ; R_{\mathrm{f}}: 0.30 ;$ IR $\left(\mathrm{cm}^{-1}\right): 3423,3232,1642,1620,1584,1455,1415,1294$,

Corresponding author: Tel.: +36 1372 2500/6591; Fax: +36 1372 2548; email:

csampai@chem.elte.hu 


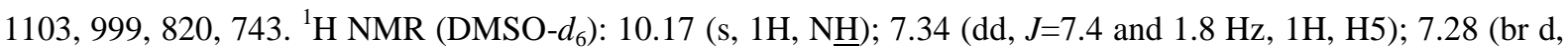
$J=7.4 \mathrm{~Hz}, 1 \mathrm{H}, \mathrm{H} 8) ; 6.98(\mathrm{td}, J=7.4$ and $1.8 \mathrm{~Hz}, 1 \mathrm{H}, \mathrm{H} 7) ; 6.92(\mathrm{td}, J=7.4$ and $1.8 \mathrm{~Hz}, 1 \mathrm{H}, \mathrm{H} 6) ; 4.84$ (s, $1 \mathrm{H}, \mathrm{H} 1)$; 4.48, 4.31, 4.17, 4.09 (4xbr s, 4x1H, H2' -5 '); 4.19 (s, 5H, $\eta^{5}-\mathrm{C}_{5} \underline{\mathrm{H}}_{5}$ ); 3.30 (dt, J=12.1 and $3.1 \mathrm{~Hz}, 1 \mathrm{H}, \mathrm{H} 3_{\mathrm{A}}$, partly overlapped by the HDO signal of the solvent); 2.99 (ddd, $J=12.1,7.6$ and $4.8 \mathrm{~Hz}, 1 \mathrm{H}, \mathrm{H} 3_{\mathrm{B}}$ ); 2.69-2.57 (overlapping m's, $2 \mathrm{H}, \mathrm{H}_{\mathrm{A}}$ and $\mathrm{H}_{\mathrm{B}}$ ); ${ }^{13} \mathrm{C}$ NMR (DMSO-d $)_{6}$ ): 137.4 (C9a); 136.6 (C8a); 127.6 (C4b); 121.2 (C7); 119.1 (C6); 118.5 (C5); 112.2 (C8); 107.4 (C4a); 92.2 (C1'); 68.6, 67.9, 67.8, 66.7 (C2' -5'); $69.3\left(\eta^{5}-\underline{C}_{5} \mathrm{H}_{5}\right)$; 52.6 (C1); 43.5 (C3); 23.3 (C4); Anal. Calcd. for $\mathrm{C}_{21} \mathrm{H}_{20} \mathrm{FeN}_{2}$ (356.25): C, 70.80; H, 5.66; N, 7.86. Found: C: 70.68; H: 5.60; N, 7.77\%.

\subsection{Pictet-Spengler cyclizations of imines $\mathbf{2} \boldsymbol{b}$ and $\mathbf{6} \boldsymbol{a}, \boldsymbol{b}$ by Method $\mathbf{G}$ :}

The conversion of the appropriate imine $(10 \mathrm{mmol})$ was performed in AcOH $(15 \mathrm{~mL})$. The workup procedure described in the previous section led to the isolation of diastereomeric mixtures of the appropriate $\beta$ carboline products $(\mathbf{3 b} / \mathbf{4 b}, \mathbf{7 a} / \mathbf{8 a}$ and $\mathbf{7 b} / \mathbf{8 b})$. (After the reactions of $\mathbf{6 a}$ and $\mathbf{6 b}$ the $\mathrm{pH}$ of the suspensions obtained by trituration of the evaporated reaction mixture with water was adjusted to 7-8 by addition of solid $\mathrm{Na}_{2} \mathrm{CO}_{3}$ in small portions.) The diastereomeric pairs were subjected to flash column chromatography on silica using DCM-MeOH (20:1 for $\mathbf{3 b} / \mathbf{4 b}, \mathbf{b}$ : 1 for $\mathbf{7 a} / \mathbf{8 a}$, and 15:1 for $\mathbf{7 b} / \mathbf{8 b})$ as eluents. The solid residues obtained by evaporation of separated bands were triturated by cold $\mathrm{MeOH}$, filtered off and dried to give $\beta$-carbolines as single diastereomers. Analytical samples were recrystallized from $\mathrm{MeOH}$.

4.4.1. Methyl (1S,3S)-1-ferrocenyl-2,3,4,9-tetrahydro-1H-pyrido[3,4-b]indole-3-carboxylate (3b)

Dark yellow solid. Yield: $2.569 \mathrm{~g}(62 \%) ; \mathrm{mp} .: 97-100{ }^{\circ} \mathrm{C} ; R_{\mathrm{f}}: 0.41 ;[\alpha]_{\mathrm{D}}^{25}:-62.0^{\circ}\left(\mathrm{CHCl}_{3} c=0.064\right.$ $\mathrm{g} / 100 \mathrm{~mL})$; IR $\left(\mathrm{cm}^{-1}\right): 3354,3204,1622,1573,1423,1380,1287,1085,975,810,748 .{ }^{1} \mathrm{H}$ NMR (DMSO- $\left.d_{6}\right)$ : 10.24 (s, $1 \mathrm{H}, \mathrm{NH}) ; 7.46$ (br d, J=7.6 Hz, 1H, H5); 7.19 (br d, J=7.6 Hz, 1H, H8); 7.02 (td, $J=7.6$ and $1.8 \mathrm{~Hz}, 1 \mathrm{H}$, H7); 6.95 (td, $J=7.6$ and $1.8 \mathrm{~Hz}, 1 \mathrm{H}, \mathrm{H} 6) ; 4.84$ (s, 1H, H1); 4.68, 4.31, 4.17, 4.10 (4xbr s, 4x1H, H2' -5'); 4.32 (s, $\left.5 \mathrm{H}, \eta^{5}-\mathrm{C}_{5} \underline{\mathrm{H}}_{5}\right) ; 4.07$ (dd, $J=11.9$ and $\left.4.4 \mathrm{~Hz}, 1 \mathrm{H}, \mathrm{H} 3\right) ; 3.90$ (s, $\left.3 \mathrm{H}, \mathrm{OCH}_{3}\right) ; 3.05$ (dd, $J=14.5$ and $4.8 \mathrm{~Hz}, 1 \mathrm{H}$, $\left.\mathrm{H} 4_{\mathrm{B}}\right) ; 2.83\left(\mathrm{dd}, J=14.5\right.$ and $\left.11.9 \mathrm{~Hz}, 1 \mathrm{H}, \mathrm{H} 4_{\mathrm{A}}\right) ;{ }^{13} \mathrm{C}$ NMR (DMSO- $\left.d_{6}\right): 138.3(\mathrm{C} 8 \mathrm{a}) ; 135.8(\mathrm{C} 9 \mathrm{a}) ; 127.0$ (C4b); 122.0 (C7); 120.3 (C6); 118.6 (C5); 112.9 (C8); 106.5 (C4a); 91.8 (C1'); $72.0\left(\eta^{5}-\underline{C}_{5} \mathrm{H}_{5}\right) ; 69.3,68.4,68.1,66.9$ (C2'-5'); 50.0 (C1); 54.7 (C3); 25.2 (C4); Anal. Calcd. for $\mathrm{C}_{23} \mathrm{H}_{22} \mathrm{FeN}_{2} \mathrm{O}_{2}$ (414.29): C, 66.68; H, 5.35; N, 6.76;. Found: C: 66.80; H: 5.31; N, 6.70\%.

\subsubsection{Methyl (1R,3S)-1-ferrocenyl-2,3,4,9-tetrahydro-1H-pyrido[3,4-b]indole-3-carboxylate (4b)}

Dark yellow solid. Yield: $0.497 \mathrm{~g}(12 \%)$; mp.: $113-115{ }^{\circ} \mathrm{C} ; R_{\mathrm{f}}: 0.53 ;[\alpha]_{\mathrm{D}}{ }^{25}:-71.7^{\circ}(\mathrm{EtOH} c=0.062$ $\mathrm{g} / 100 \mathrm{~mL})$; IR $\left(\mathrm{cm}^{-1}\right): 3408,3222,1615,1573,1445,1364,1186,1103,988,814,740 .{ }^{1} \mathrm{H}$ NMR (DMSO- $\left.d_{6}\right)$ : 10.52 (s, 1H, N $\underline{\mathrm{H}}$ ); 7.42 (br d, J=7.6 Hz, 1H, H5); 7.36 (br d, J=7.6 Hz, 1H, H8); 7.00 (br t, J=7.6 Hz, 1H, H7); 6.85 (br t, $J=7.6 \mathrm{~Hz}, 1 \mathrm{H}, \mathrm{H6}) ; 5.24$ (s, 1H, H1); 4.53, 4.29, 4.22, 4.07 (4xbr s, 4x1H, H2' -5'); 4.13 (dd, , $J=5.4$ and $4.2 \mathrm{~Hz}, 1 \mathrm{H}, \mathrm{H} 3) ; 3.96\left(\mathrm{~s}, 5 \mathrm{H}, \eta^{5}-\mathrm{C}_{5} \underline{\mathrm{H}}_{5}\right) ; 3.73\left(\mathrm{~s}, 3 \mathrm{H}, \mathrm{OCH}_{3}\right) ; 3.19\left(\mathrm{dd}, J=15.6\right.$ and $\left.4.2 \mathrm{~Hz}, 1 \mathrm{H}, \mathrm{H} 4_{\mathrm{B}}\right) ; 2.83$ (dd, $J=15.6$ and $\left.5.4 \mathrm{~Hz}, 1 \mathrm{H}, \mathrm{H} 4_{\mathrm{A}}\right) ;{ }^{13} \mathrm{C}$ NMR (DMSO-d $)$ : 136.1 (C8a); 132.3 (C9a); 127.4 (C4b); 122.4 (C7); 120.2 (C6); 119.4 (C5); 111.6 (C8); 106.2 (C4a); $90.3\left(\mathrm{C} 1^{\prime}\right) ; 70.7\left(\eta^{5}-\underline{C}_{5} \mathrm{H}_{5}\right) ; 68.1,67.5,67.0,66.5\left(\mathrm{C} 2^{\prime}-5^{\prime}\right)$; 50.0 (C1); 51.2 (C3); 24.0 (C4); Anal. Calcd. for $\mathrm{C}_{23} \mathrm{H}_{22} \mathrm{FeN}_{2} \mathrm{O}_{2}$ (414.29): C, 66.68; H, 5.35; N, 6.76;. Found: C: $66.77 ; \mathrm{H}: 5.44 ; \mathrm{N}, 6.82 \%$.

\subsection{3. $\left(S_{p}\right)-((S)-5-(2,3,4,9-T e t r a h y d r o-1 H$-pyrido[3,4-b]indol-1-yl))ferrocene-1-carboxylic acid (7a)}

Orange solid. Yield: $1.241 \mathrm{~g}(31 \%) ; \mathrm{mp} .: 193-195{ }^{\circ} \mathrm{C} ; R_{\mathrm{f}}: 0.36 ;[\alpha]_{\mathrm{D}}{ }^{25}:+20.9^{\circ}\left(\mathrm{CHCl}_{3} c=0.033 \mathrm{~g} / 100\right.$ $\mathrm{mL})$; IR $\left(\mathrm{cm}^{-1}\right): \sim 3600-2700,1612,1563,1440,1365,1265,1106,1005,815,735 .{ }^{1} \mathrm{H}$ NMR (DMSO-d $\left.d_{6}\right): 10.20$ (s, 1H, N $\underline{H}$ ); 7.45 (br d, J=7.5 Hz, 1H, H5); 7.35 (br d, J=7.5 Hz, 1H, H8); 7.09 (td, J=7.5 and 1.8 Hz, 1H, H7); 7.04 (td, $J=7.5$ and $1.8 \mathrm{~Hz}, 1 \mathrm{H}, \mathrm{H} 6) ; 5.88$ (s, 1H, H1); 4.80 (br s, 1H, H3'); 4.57 (br s, 1H, H4'); 4.51 (br s, $1 \mathrm{H}$, $\left.\mathrm{H}^{\prime}{ }^{\prime}\right) ; 4.37\left(\mathrm{~s}, 5 \mathrm{H}, \eta^{5}-\mathrm{C}_{5} \underline{\mathrm{H}}_{5}\right) ; 3.51$ (ddd, , $J=12.6,6.9$ and $\left.5.0 \mathrm{~Hz}, 1 \mathrm{H}, \mathrm{H} 3_{\mathrm{A}}\right) ; 3.35$ (ddd, $J=12.6,6.2$ and $4.5 \mathrm{~Hz}$, $1 \mathrm{H}, \mathrm{H} 3_{\mathrm{B}}$ ); 3.01-2.79 (overlapping m's, $2 \mathrm{H}, \mathrm{H} 4_{\mathrm{A}}$ and $\left.\mathrm{H}_{\mathrm{B}}\right) ;{ }^{13} \mathrm{C} \mathrm{NMR}\left(\mathrm{DMSO}-d_{6}\right): 171.0\left(\mathrm{CO}_{2} \mathrm{H}\right) ; 137.8(\mathrm{C} 8 \mathrm{a})$; 133.3 (C9a); 127.5 (C4b); 122.2 (C7); 119.7 (C6); 119.2 (C5); 112.9 (C8); 104.7 (C4a); 90.8 (C1'); 73.8 (C5'); $71.5\left(\mathrm{C} 2^{\prime}\right) ; 71.0\left(\eta^{5}-\mathrm{C}_{5} \mathrm{H}_{5}\right) ; 70.6\left(\mathrm{C}^{\prime}\right) ; 70.2\left(\mathrm{C}^{\prime}\right)$ ); $53.1(\mathrm{C} 1) ; 43.5(\mathrm{C} 3) ; 20.2(\mathrm{C} 4)$; Anal. Calcd. for $\mathrm{C}_{22} \mathrm{H}_{20} \mathrm{FeN}_{2} \mathrm{O}_{2}$ (400.26): C, 66.02; H, 5.04; N, 7.00; Found: C: 65.97; H: 5.13; N, 6.94\%.

4.4.4. 2-( $\quad$ ( carboxylic acid $(\mathbf{7 b})$

Red solid. Yield: $1.512 \mathrm{~g}(33 \%)$; mp.: $181-184{ }^{\circ} \mathrm{C} ; R_{\mathrm{f}}: 0.55 ;[\alpha]_{\mathrm{D}}{ }^{25}:-27.5^{\circ}\left(\mathrm{CHCl}_{3} c=0.060 \mathrm{~g} / 100\right.$ $\mathrm{mL})$; IR $\left(\mathrm{cm}^{-1}\right): \sim 3500-2900,1746,1603,1540,1438,1364,1267,1219,1106,1002,915,819,737 .{ }^{1} \mathrm{H}$ NMR (DMSO- $d_{6}$ ): 10.32 (s, $1 \mathrm{H}, \mathrm{N} \underline{\mathrm{H}}$, indole); 7.44 (br d, $\left.J=7.7 \mathrm{~Hz}, 1 \mathrm{H}, \mathrm{H} 5\right) ; 7.25$ (br d, J=7.7 Hz, 1H, H8); 7.03 (br t,

Corresponding author: Tel.: +36 1372 2500/6591; Fax: +36 1372 2548; email:

csampai@chem.elte.hu 
$J=7.7 \mathrm{~Hz}, 1 \mathrm{H}, \mathrm{H} 7) ; 6.97$ (td, $J=7.7$ and $1.7 \mathrm{~Hz}, 1 \mathrm{H}, \mathrm{H6}$ ); 5.17 (s, 1H, H1); 4.78 (br s, 1H, H5'); 4.72 (br s, $1 \mathrm{H}$, H3'); 4.61 (t, $J=2.1 \mathrm{~Hz}, 1 \mathrm{H}, \mathrm{H}^{\prime}$ '); $4.46\left(\mathrm{~s}, 5 \mathrm{H}, \eta^{5}-\mathrm{C}_{5} \mathrm{H}_{5}\right) ; 4.10(\mathrm{dd}, J=11.7$ and $4.3 \mathrm{~Hz}, 1 \mathrm{H}, \mathrm{H} 3) ; 3.87$ (s, $3 \mathrm{H}$, $\left.\mathrm{CO}_{2} \mathrm{CH}_{3}\right) ; 3.18\left(\mathrm{dd},, J=14.9\right.$ and $\left.4.3 \mathrm{~Hz}, 1 \mathrm{H}, \mathrm{H} 4_{\mathrm{A}}\right) ; 2.88\left(\mathrm{ddd}, J=14.9,11.7\right.$ and $\left.1.9 \mathrm{~Hz}, 1 \mathrm{H}, \mathrm{H} 4_{\mathrm{B}}\right) ;{ }^{13} \mathrm{C} \mathrm{NMR}^{2}$ $\left(\mathrm{DMSO}-d_{6}\right): 172.4\left(\mathrm{CO}_{2} \mathrm{CH}_{3}\right) ; 171.2\left(\mathrm{CO}_{2}{ }^{-}\right) ; 137.0$ (C8a); 133.1 (C9a); 126.5 (C4b); 121.7 (C7); 119.4 (C6);

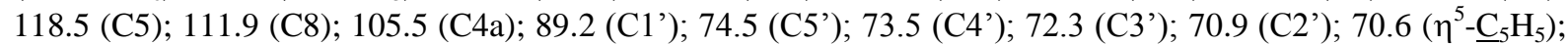
55.9 (C3); $52.8\left(\mathrm{CO}_{2} \mathrm{CH}_{3}\right) ; 51.4(\mathrm{C} 1) ; 24.3(\mathrm{C} 4)$; Anal. Calcd. for $\mathrm{C}_{24} \mathrm{H}_{22} \mathrm{FeN}_{2} \mathrm{O}_{4}$ (458.30): C, 62.90; H, 4.84; N, 6.11; Found: C: 62.84; H: 4.95; N, 6.14\%.

\subsection{5. $\left(S_{p}\right)-((R)-5-(2,3,4,9-T e t r a h y d r o-1 H$-pyrido[3,4-b]indol-1-yl))ferrocene-1-carboxylic acid $(8 a)$}

Orange solid. Yield: $0.112 \mathrm{~g}(14 \%)$; mp.: $162-164{ }^{\circ} \mathrm{C} ; R_{\mathrm{f}}: 0.49 ;[\alpha]_{\mathrm{D}}{ }^{25}:-20.1^{\circ}\left(\mathrm{CHCl}_{3} c=0.028 \mathrm{~g} / 100 \mathrm{~mL}\right)$; IR $\left(\mathrm{cm}^{-1}\right): \sim 3650-2750,1621,1560,1451,1357,1270,1103,995,808,740 ;{ }^{1} \mathrm{H}$ NMR (DMSO- $\left.d_{6}\right): 10.68(\mathrm{~s}, 1 \mathrm{H}$, $\mathrm{NH}$, indole); 7.46 (br d, $J=7.5 \mathrm{~Hz}, 1 \mathrm{H}, \mathrm{H} 5) ; 7.25$ (br d, $J=7.5 \mathrm{~Hz}, 1 \mathrm{H}, \mathrm{H} 8$ ); 7.05 (td, $J=7.5$ and 1.8 Hz, 1H, H7); 7.01 (td, $J=7.5$ and $1.8 \mathrm{~Hz}, 1 \mathrm{H}, \mathrm{H} 6) ; 5.45$ (s, 1H, H1); 4.85 (br s, 1H, H3'); 4.61 (br s, 1H, H5'); 4.48 (br s, $1 \mathrm{H}$, H4'); 4.02 (s, 5H, $\left.\eta^{5}-\mathrm{C}_{5} \underline{\mathrm{H}}_{5}\right) ; 3.73$ (ddd, $J=12.5,6.2$ and $4.0 \mathrm{~Hz}, 1 \mathrm{H}, \mathrm{H}_{\mathrm{A}}$ ); 3.23 (ddd, $J=12.5,5.2$ and $4.1 \mathrm{~Hz}$, $\left.1 \mathrm{H}, \mathrm{H} 3_{\mathrm{B}}\right) ; 2.94-2.74$ (overlapping m's, $2 \mathrm{H}, \mathrm{H} 4_{\mathrm{A}}$ and $\left.\mathrm{H}_{\mathrm{B}}\right) ;{ }^{13} \mathrm{C}$ NMR (DMSO- $\left.d_{6}\right): 170.8\left(\mathrm{CO}_{2} \mathrm{H}\right) ; 137.0(\mathrm{C} 8 \mathrm{a})$; 132.9 (C9a); 127.1 (C4b); 121.7 (C7); 120.0 (C6); 118.6 (C5); 112.5 (C8); 106.9 (C4a); 89.1 (C1'); 74.6 (C5'); 72.0 (C2'); $70.8\left(\eta^{5}-\underline{C}_{5} \mathrm{H}_{5}\right) ; 70.6\left(\mathrm{C}^{\prime}\right.$ '); $70.0(\mathrm{C} 3$ '); 52.2 (C1); 41.3 (C3); 20.6 (C4);

4.4.6. 2-( 2 p)-((1R,3S)-3-(Methoxycarbonyl)-2,3,4,9-tetrahydro-1H-pyrido[3,4-b]indol-1-yl)ferrocene-1carboxylic acid $(\mathbf{8 b})$

Red solid. Yield: $1.283 \mathrm{~g}(28 \%)$; mp.: $174-178{ }^{\circ} \mathrm{C} ; R_{\mathrm{f}}: 0.48 ;[\alpha]_{\mathrm{D}}{ }^{25}:-63.4^{\circ}\left(\mathrm{CHCl}_{3} c=0.040 \mathrm{~g} / 100\right.$ $\mathrm{mL})$; IR $\left(\mathrm{cm}^{-1}\right): \sim 3450-2900,1742,1607,1553,1441,1362,1259,1224,1102,998,905,822,741 .{ }^{1} \mathrm{H}$ NMR (DMSO-d $d_{6}$ ): 10.34 (s, 1H, NH, indole); 7.44 (br d, $J=7.7 \mathrm{~Hz}, 1 \mathrm{H}, \mathrm{H} 5$ ); 7.30 (br d, $J=7.7 \mathrm{~Hz}, 1 \mathrm{H}, \mathrm{H} 8$ ); 7.06 (br t, $J=7.7 \mathrm{~Hz}, 1 \mathrm{H}, \mathrm{H} 7) ; 6.98(\mathrm{td}, J=7.7$ and $1.7 \mathrm{~Hz}, 1 \mathrm{H}, \mathrm{H6}) ; 5.56(\mathrm{~s}, 1 \mathrm{H}, \mathrm{H1}) ; 4.74$ (br s, 1H, H3'); 4.57 (br s, $1 \mathrm{H}$, H5'); 4.55 (br s, 1H, H4'); 4.27 (dd, J=5.7 and $\left.4.2 \mathrm{~Hz}, 1 \mathrm{H}, \mathrm{H}_{\mathrm{A}}\right) ; 3.85$ (s, 5H, $\left.\eta^{5}-\mathrm{C}_{5} \underline{\mathrm{H}}_{5}\right) ; 3.68\left(\mathrm{~s}, 3 \mathrm{H}, \mathrm{CO}_{2} \mathrm{C}_{3}\right)$; 3.15-3.11 (overlapping m's, $2 \mathrm{H}, \mathrm{H}_{4}$ and $\left.\mathrm{H}_{\mathrm{B}}\right) ;{ }^{13} \mathrm{C}$ NMR (DMSO- $\left.d_{6}\right): 173.4\left(\mathrm{CO}_{2} \mathrm{CH}_{3}\right) ; 170.3\left(\underline{\mathrm{CO}}{ }_{2} \mathrm{H}\right) ; 137.3$ (C8a); 133.4 (C9a); 127.0 (C4b); 122.2 (C7); 119.7 (C6); 118.9 (C5); 112.4 (C8); 105.2 (C4a); 89.7 (C1'); 74.4 (C5'); $71.2\left(\eta^{5}-\underline{C}_{5} \mathrm{H}_{5}\right) ; 70.9\left(\mathrm{C}^{\prime}\right.$ '); 70.5 (C4'); 70.2 (C3'); $53.1(\mathrm{C} 3) ; 52.3\left(\mathrm{CO}_{2} \underline{\mathrm{CH}}_{3}\right) ; 49.7$ (C1); 23.6 (C4); Anal. Calcd. for $\mathrm{C}_{24} \mathrm{H}_{22} \mathrm{FeN}_{2} \mathrm{O}_{4}$ (458.30): C, 62.90; H, 4.84; N, 6.11; Found: C: 62.98; H: 4.90; N, 6.05\%.

4.5. Cyclization of $7 a$ with cyanuricfluoride: synthesis of $\left(12 b S, S_{p}, P\right)-4-O x o-6,7,12,12 b$-tetrahydro-4Hferroceno[1,2]indolizino[8,7-b]indole-5-one (9a) by Method $H$

$\beta$-Carboline 7a (4.003 g, $10 \mathrm{mmol})$ was dissolved in dry DCM $(50 \mathrm{~mL})$. To this solution pyridine $(1.650$ $\mathrm{mL})$ and cyanuricfluoride $(3.605 \mathrm{~mL})$ were added at $0{ }^{\circ} \mathrm{C}$. After a few minutes the cooling bath was removed and the mixture was stirred at $\mathrm{rt}$ for 90 minutes under Ar. After addition of crushed ice the resulted suspension was filtered, the organic phase was separated, washed with cold water $(3 \times 50 \mathrm{~mL})$, dried over $\mathrm{Na}_{2} \mathrm{SO}_{4}$, filtered and evaporated. The crude lactame was purified by flash column chromatography on silica using DCM-MeOH (30:1) as eluent. The orange band was collected, evaporated and triturated with cold EtOH to obtain 9a in pure form as red needles. Yield: $1.477 \mathrm{~g}(45 \%)$; mp.: $103-105{ }^{\circ} \mathrm{C} ; R_{\mathrm{f}}: 0.74 ;[\alpha]_{\mathrm{D}}{ }^{25}:+55.4^{\circ}\left(\mathrm{CHCl}_{3} c=0.048 \mathrm{~g} / 100 \mathrm{~mL}\right) ; \mathrm{IR}$ $\left(\mathrm{cm}^{-1}\right): 3222,1621,1521,1447,1368,1303,1247,1158,1106,1003,, 829,742 .{ }^{1} \mathrm{H} \mathrm{NMR}\left(\mathrm{CDCl}_{3}\right): 9.11(\mathrm{~s}, 1 \mathrm{H}$, $\mathrm{NH}$ ); 7.59 (br d, $J=7.6 \mathrm{~Hz}, 1 \mathrm{H}, \mathrm{H} 8) ; 7.48$ (br d, $J=7.6 \mathrm{~Hz}, 1 \mathrm{H}, \mathrm{H} 11) ; 7.27$ (td, $J=7.6$ and $1.9 \mathrm{~Hz}, 1 \mathrm{H}, \mathrm{H} 10) ; 7.18$ (td, $J=7.6$ and $1.9 \mathrm{~Hz}, 1 \mathrm{H}, \mathrm{H} 9) ; 6.95$ (s, 1H, H12b); 5.18 (br dd, $J=13.1$ and $5.2 \mathrm{~Hz}, 1 \mathrm{H}, \mathrm{H} 6_{\mathrm{B}}$ ); 4.96 (br s, $1 \mathrm{H}$, $\mathrm{H} 1$ ); 4.59 (t, $J=2.0 \mathrm{~Hz}, 1 \mathrm{H}, \mathrm{H} 2) ; 4.55$ (br s, $1 \mathrm{H}, \mathrm{H} 3$ ); 4.06 (s, $5 \mathrm{H}, \eta^{5}-\mathrm{C}_{5} \underline{\mathrm{H}}_{5}$ ); 3.79 (ddd, $J=13.1,11.6$ and $5.2 \mathrm{~Hz}$, $\left.1 \mathrm{H}, \mathrm{H6}_{\mathrm{A}}\right)$; 3.13-3.12 (overlapping m's, $2 \mathrm{H}, \mathrm{H}_{\mathrm{A}}$ and $\left.\mathrm{H} 7_{\mathrm{B}}\right) ;{ }^{13} \mathrm{C} \mathrm{NMR}\left(\mathrm{CDCl}_{3}\right): 168.3(\mathrm{C} 4) ; 135.7(\mathrm{C} 11 \mathrm{a}) ; 133.1$ (C12a); 125.8 (C7b); 123.2 (C10); 120.2 (C9); 119.1 (C8); 111.4 (C11); 107.9 (C7a); 92.3 (C12c); 74.2 (C3); $72.5(\mathrm{C} 1) ; 71.6(\mathrm{C} 2) ; 71.5\left(\eta^{5}-\mathrm{C}_{5} \mathrm{H}_{5}\right) ; 60.0(\mathrm{C} 3 \mathrm{a}) ; 50.0(\mathrm{C} 12 \mathrm{~b}) ; 41.3(\mathrm{C} 6) ; 21.3(\mathrm{C} 7)$; Anal. Calcd. for $\mathrm{C}_{22} \mathrm{H}_{18} \mathrm{FeN}_{2} \mathrm{O}$ (382.24): C, 69.13; H, 4.75; N, 7.33; Found: C: 69.23; H: 4.80; N, 7.24\%.

\subsection{Cyclization of $\mathbf{6} \boldsymbol{a}, \boldsymbol{b}, \mathbf{7} \boldsymbol{a}, \boldsymbol{b}$ and $\mathbf{8} \boldsymbol{a}, \boldsymbol{b}$ with carbonyldiimidazole by Method I}

The mixture of $5 \mathrm{mmol}$ of the corresponding imine $(\mathbf{6 a}, \mathbf{b})$ or $\beta$-carboline $(\mathbf{7 a}, \mathbf{b}$ and $\mathbf{8 a}, \mathbf{b})$, carbonyldiimidazole (CDI, $0.474 \mathrm{~g}, 6 \mathrm{mmol})$ and $\mathrm{NEt}_{3} \cdot \mathrm{HCl}(0.069 \mathrm{~g}, 1 \mathrm{mmol})$ disslolved in dry DMF $(10 \mathrm{~mL})$ was stirred under an $\mathrm{Ar}$ atmosphere at $50{ }^{\circ} \mathrm{C}$ for $30 \mathrm{~min}$. The reaction mixture was poured on ice-water and the resulted precipitate was filtered off, washed with water, dried and subjected to flash column chromatography on silica using DCM-MeOH (30:1) as eluent. Lactames 9a,b, 9b/inv 12a,b, 14b and cyclopenta[7,8]azonino[5,4$b$ ]indole $\mathbf{1 3 b}$ obtained by the evaporation of the separated bands were crystallized by cold $\mathrm{MeOH}$. The analytical and spectral data of lactame 9a $(1.147 \mathrm{~g}, 60 \%$ from $7 \mathbf{a}$ and $0.456 \mathrm{~g}, 24 \%$ from $\mathbf{6 a})$ were practically identical to those measured for the sample prepared by Method $H$.

Corresponding author: Tel.: +36 1372 2500/6591; Fax: +36 1372 2548; email: csampai@chem.elte.hu 


\subsection{1. (12bR, $\left.S_{p}, M\right)-4-O x o-6,7,12,12 b$-tetrahydro-4H-ferroceno[1,2]indolizino[8,7-b]indole-5-one (12a)}

Red solid. Yield: $2.219 \mathrm{~g}(58 \%$ by from $\mathbf{6 a}) ; 1.682 \mathrm{~g}(44 \%$ by from $\mathbf{8 a})$; mp.: 126-128 ${ }^{\circ} \mathrm{C} ; R_{\mathrm{f}}: 0.82$; $[\alpha]_{\mathrm{D}}^{25}:+56.3^{\circ}\left(\mathrm{CHCl}_{3} c=0.024 \mathrm{~g} / 100 \mathrm{~mL}\right) ;$ IR $\left(\mathrm{cm}^{-1}\right): \sim 3400-2950,1685,1611,1559,1451,1375,1270,1233$, 1106, 901,830, 749. ${ }^{1} \mathrm{H}$ NMR $\left(\mathrm{CDCl}_{3}\right): 9.24(\mathrm{~s}, 1 \mathrm{H}, \mathrm{NH}) ; 7.54$ (br d, $\left.J=7.8 \mathrm{~Hz}, 1 \mathrm{H}, \mathrm{H} 8\right) ; 7.36$ (br d, $J=7.8 \mathrm{~Hz}$, $1 \mathrm{H}, \mathrm{H} 11$ ); 7.21 (br t, $J=7.8,1 \mathrm{H}, \mathrm{H} 10) ; 7.14$ (td, $J=7.6$ and $1.9 \mathrm{~Hz}, 1 \mathrm{H}, \mathrm{H} 9$ ); 6.33 (s, 1H, H12b); 4.98 (ddd, $J=14.6,5.4$ and $2.0 \mathrm{~Hz}, 1 \mathrm{H}, \mathrm{H}_{\mathrm{A}}$ ); 4.78 (br s, $\left.1 \mathrm{H}, \mathrm{H} 1\right) ; 4.52(\mathrm{t}, J=2.2 \mathrm{~Hz}, 1 \mathrm{H}, \mathrm{H} 2) ; 4.41$ (br s, 1H, H3); 3.68 (s, $5 \mathrm{H}, \eta^{5}-\mathrm{C}_{5} \underline{\mathrm{H}}_{5}$ ); 3.54 (ddd, $\mathrm{J}=14.6,11.2$ and $5.4 \mathrm{~Hz}, 1 \mathrm{H}, \mathrm{H6}_{\mathrm{B}}$ ); 3.25-3.18 (overlapping m's, $2 \mathrm{H}, \mathrm{H}_{\mathrm{A}}$ and $\mathrm{H}_{\mathrm{B}}$ ); ${ }^{13} \mathrm{C}$ NMR (CDCl $)$ :167.1 (C4); 131.6 (C11a); 129.8 (C12a); 124.6 (C7b); 123.0 (C10); 121.0 (C9); 119.4 (C8); 112.1 (C11); 106.7 (C7a); 90.9 (C12c); 74.0 (C3); $71.1(\mathrm{C} 1) ; 70.6(\mathrm{C} 2) ; 70.2\left(\eta^{5}-\mathrm{C}_{5} \mathrm{H}_{5}\right) ; 63.1(\mathrm{C} 3 \mathrm{a}) ; 48.2(\mathrm{C} 12 \mathrm{~b}) ; 41.0$ (C6); 21.6 (C7); Anal. Calcd. for $\mathrm{C}_{22} \mathrm{H}_{18} \mathrm{FeN}_{2} \mathrm{O}$ (382.24): C, 69.13; H, 4.75; N, 7.33; Found: C: 69.01; H: 4.82; $\mathrm{N}, 7.19 \%$.

4.6.2. Methyl (6S,12bS, $\left.S_{p}, P\right)$-4-oxo-6,7,12,12b-tetrahydro-4H-ferroceno[1,2]indolizino[8,7-b]indole-6carboxylate $(\mathbf{9 b})$

Red solid. Yield: $0.220 \mathrm{~g}(5 \%$ from $6 \mathbf{b}) ; 1.631 \mathrm{~g}(37 \%$ from $7 \mathbf{b}) ; \mathrm{mp} .: 101-104{ }^{\circ} \mathrm{C} ; R_{\mathrm{f}}: 0.57 ;[\alpha]_{\mathrm{D}}{ }^{25}$ : $-32.9^{\circ}\left(\mathrm{CHCl}_{3} c=0.039 \mathrm{~g} / 100 \mathrm{~mL}\right) ; \mathrm{IR}\left(\mathrm{cm}^{-1}\right): \sim 3400-2850,1740,1628,1543,1451,1369,1262,1230,1105$, 992, 900,811, 751. ${ }^{1} \mathrm{H}$ NMR $\left(\mathrm{CDCl}_{3}\right): 8.81(\mathrm{~s}, 1 \mathrm{H}, \mathrm{N} \underline{\mathrm{H}}) ; 7.58(\mathrm{dd}, J=7.6$ and $1.8 \mathrm{~Hz}, 1 \mathrm{H}, \mathrm{H} 8) ; 7.47$ (br d, $J=7.6$ $\mathrm{Hz}, 1 \mathrm{H}, \mathrm{H} 11$ ); 7.06 (td, J=7.6 and $1.8 \mathrm{~Hz}, 1 \mathrm{H}, \mathrm{H} 10$ ); 6.98 (td, $J=7.6$ and $1.9 \mathrm{~Hz}, 1 \mathrm{H}, \mathrm{H} 9$ ); 5.89 (s, 1H, H12b); 4.91 (br s, $1 \mathrm{H}, \mathrm{H} 1) ; 4.55$ (br s, $1 \mathrm{H}, \mathrm{H} 3) ; 4.27$ (s, 5H, $\left.\eta^{5}-\mathrm{C}_{5} \underline{\mathrm{H}}_{5}\right) ; 4.22$ (t, $\left.J=2.0 \mathrm{~Hz}, 1 \mathrm{H}, \mathrm{H} 2\right) ; 4.18$ (dd, $J=11.8$ and $\left.4.3 \mathrm{~Hz}, 1 \mathrm{H}, \mathrm{H6}_{\mathrm{A}}\right) ; 3.97\left(\mathrm{~s}, 3 \mathrm{H}, \mathrm{CO}_{2} \mathrm{CH}_{3}\right) ; 3.29\left(\mathrm{dd}, J=15.9\right.$ and $\left.11.8 \mathrm{~Hz}, 1 \mathrm{H}, \mathrm{H}_{\mathrm{B}}\right) ; 3.09$ (dd, $J=15.9$ and $4.3 \mathrm{~Hz}$, $1 \mathrm{H}, \mathrm{H} 7 \mathrm{~A}) ;{ }^{13} \mathrm{C}$ NMR $\left(\mathrm{CDCl}_{3}\right): 173.2(\mathrm{C} 4) ; 170.2\left(\mathrm{CO}_{2} \mathrm{CH}_{3}\right) ; 136.3(\mathrm{C} 11 \mathrm{a}) ; 130.7(\mathrm{C} 12 \mathrm{a}) ; 126.4(\mathrm{C} 7 \mathrm{~b}) ; 122.4$ (C10); 119.9 (C9); 118.6 (C8); 111.4 (C11); 105.7 (C7a); 94.0 (C12c); 75.5 (C3a); 72.6 (C2); 70.2 (C3); 68.1 (C1); $71.0\left(\eta^{5}-\underline{C}_{5} \mathrm{H}_{5}\right) ; 55.6(\mathrm{C} 6) ; 52.5\left(\mathrm{CO}_{2} \mathrm{CH}_{3}\right) ; 51.1(\mathrm{C} 12 \mathrm{~b}) ; 23.4(\mathrm{C} 7)$; Anal. Calcd. for $\mathrm{C}_{24} \mathrm{H}_{20} \mathrm{FeN}_{2} \mathrm{O}_{3}$ (440.28): C, 65.47; H, 4.58; N, 6.36; Found: C: 65.42; H: 4.68; N, 6.50\%.

4.6.3. Methyl $\left(6 S, 12 b S, S_{p}, M\right)-4$-oxo-6,7,12,12b-tetrahydro-4H-ferroceno[1,2]indolizino[8,7-b]indole-6carboxylate $(\mathbf{9 b} / \mathbf{i n v})$

Red solid. Yield: $0.661 \mathrm{~g}\left(15 \%\right.$ from 6b); mp.: $92-95{ }^{\circ} \mathrm{C} ; R_{\mathrm{f}}: 0.65 ;[\alpha]_{\mathrm{D}}{ }^{25}:-27.6^{\circ}\left(\mathrm{CHCl}_{3} c=0.041\right.$ $\mathrm{g} / 100 \mathrm{~mL}) ; \mathrm{IR}\left(\mathrm{cm}^{-1}\right): \sim 3450-2850,1742,1634,1543,1472,1381,1242,1222,1121,1008,919,835,772 .{ }^{1} \mathrm{H}$ NMR $\left(\mathrm{CDCl}_{3}\right): 8.29(\mathrm{~s}, 1 \mathrm{H}, \mathrm{NH}) ; 7.50$ (br d, J=7.7 Hz, 1H, H8); 7.35 (br d, J=7.7 Hz, 1H, H11); 7.19 (td, $J=7.7$ and $1.8 \mathrm{~Hz}, 1 \mathrm{H}, \mathrm{H} 10) ; 7.13$ (td, J=7.7 and $1.8 \mathrm{~Hz}, 1 \mathrm{H}, \mathrm{H} 9) ; 6.30$ (s, 1H, H12b); 5.64 (d, J=7.1 Hz, 1H, H6 A $_{\text {); }}$ 4.94 (br s, $1 \mathrm{H}, \mathrm{H} 1) ; 4.70$ (br s, $1 \mathrm{H}, \mathrm{H} 3) ; 4.31\left(\mathrm{~s}, 5 \mathrm{H}, \eta^{5}-\mathrm{C}_{5} \underline{\mathrm{H}}_{5}\right) ; 4.29(\mathrm{t}, J=2.0 \mathrm{~Hz}, 1 \mathrm{H}, \mathrm{H} 2) ; 3.78(\mathrm{~s}, 3 \mathrm{H}$, $\left.\mathrm{CO}_{2} \mathrm{CH}_{3}\right) ; 3.41\left(\mathrm{~d}, J=15.9 \mathrm{~Hz}, 1 \mathrm{H}, \mathrm{H} 7_{\mathrm{B}}\right) ; 3.22\left(\mathrm{dd}, J=15.9\right.$ and $\left.7.1 \mathrm{~Hz}, 1 \mathrm{H}, \mathrm{H} 7_{\mathrm{A}}\right) ;{ }^{13} \mathrm{C} \mathrm{NMR}\left(\mathrm{CDCl}_{3}\right): 172.3(\mathrm{C} 4)$; $172.0\left(\mathrm{CO}_{2} \mathrm{CH}_{3}\right) ; 136.1$ (C11a); 130.7 (C12a); 126.6 (C7b); 122.6 (C10); 120.1 (C9); 118.7 (C8); 111.1 (C11); 106.7 (C7a); 95.1 (C12c); 76.5 (C3a); $72.6(\mathrm{C} 2) ; 71.0\left(\eta^{5}-\mathrm{C}_{5} \mathrm{H}_{5}\right) ; 64.0(\mathrm{C} 1) ; 62.4(\mathrm{C} 3) ; 53.5(\mathrm{C} 12 \mathrm{~b}) ; 52.6$ $\left(\mathrm{CO}_{2} \mathrm{CH}_{3}\right) ; 50.1$ (C6); 24.1 (C7); Anal. Calcd. for $\mathrm{C}_{24} \mathrm{H}_{20} \mathrm{FeN}_{2} \mathrm{O}_{3}$ (440.28): C, 65.47; H, 4.58; N, 6.36; Found: C: $65.30 ; \mathrm{H}: 4.70 ; \mathrm{N}, 6.29 \%$.

4.6.4. Methyl $\left(6 S, 12 b R, S_{p}, M\right)-4$-oxo-6,7,12,12b-tetrahydro-4H-ferroceno[1,2]indolizino[8,7-b]indole-6carboxylate (12b)

Red solid. Yield: $1.167 \mathrm{~g}(53 \%$ from $6 \mathbf{b}) ; 0.572 \mathrm{~g}\left(26 \%\right.$ from 8b); mp.: 116-118 ${ }^{\circ} \mathrm{C} ; R_{\mathrm{f}}: 0.68 ;[\alpha]_{\mathrm{D}}{ }^{25}$ : $+75.0^{\circ}\left(\mathrm{CHCl}_{3} c=0.046 \mathrm{~g} / 100 \mathrm{~mL}\right) ; \mathrm{IR}\left(\mathrm{cm}^{-1}\right): \sim 3500-2850,1748,1630,1549,1442,1370,1284,1220,1113$, 1002, 905, 820, 764; ${ }^{1} \mathrm{H}$ NMR $\left(\mathrm{CDCl}_{3}\right): 9.17$ (s, 1H, NH); 7.59 (br d, J=7.8 Hz, 1H, H8); 7.47 (br d, $J=7.8 \mathrm{~Hz}$, 1H, H11); 7.06 (br t, $J=7.8 \mathrm{~Hz}, 1 \mathrm{H}, \mathrm{H} 10) ; 6.98$ (br t, $J=7.8 \mathrm{~Hz}, 1 \mathrm{H}, \mathrm{H} 9$ ); 5.82 (s, 1H, H12b); 5.66 (d, $J=7.5 \mathrm{~Hz}$, $1 \mathrm{H}, \mathrm{H6}_{\mathrm{A}}$ ); 4.73 (br s, $\left.1 \mathrm{H}, \mathrm{H} 1\right) ; 4.71$ (br s, $\left.1 \mathrm{H}, \mathrm{H} 3\right) ; 4.33$ (t, J=2.2 Hz, 1H, H2); $3.70\left(\mathrm{~s}, 5 \mathrm{H}, \eta^{5}-\mathrm{C}_{5} \underline{\mathrm{H}}_{5}\right) ; 3.67(\mathrm{~s}$, $\left.3 \mathrm{H}, \mathrm{CO}_{2} \mathrm{CH}_{3}\right) ; 3.56\left(\mathrm{~d}, J=15.9 \mathrm{~Hz}, 1 \mathrm{H}, \mathrm{H} 7_{\mathrm{B}}\right) ; 3.24\left(\mathrm{dd}, J=15.9\right.$ and $\left.7.5 \mathrm{~Hz}, 1 \mathrm{H}, \mathrm{H} 7_{\mathrm{A}}\right) ;{ }^{13} \mathrm{C} \mathrm{NMR}\left(\mathrm{CDCl}_{3}\right): 171.6$ $\left(\mathrm{CO}_{2} \mathrm{CH}_{3}\right) ; 171.3(\mathrm{C} 4) ; 136.1(\mathrm{C} 11 \mathrm{a}) ; 132.4(\mathrm{C} 12 \mathrm{a}) ; 126.56(\mathrm{C} 7 \mathrm{~b}) ; 122.4(\mathrm{C} 10) ; 119.9(\mathrm{C} 9) ; 118.6(\mathrm{C} 8) ; 111.3$ $(\mathrm{C} 11) ; 105.4(\mathrm{C} 7 \mathrm{a}) ; 94.8(\mathrm{C} 12 \mathrm{c}) ; 78.3(\mathrm{C} 3 \mathrm{a}) ; 72.4(\mathrm{C} 2) ; 69.8\left(\eta^{5}-\mathrm{C}_{5} \mathrm{H}_{5}\right) ; 62.9(\mathrm{C} 1) ; 61.8(\mathrm{C} 3) ; 52.4\left(\mathrm{CO}_{2} \mathrm{CH}_{3}\right)$; 51.9 (C12b); 50.2 (C6); 24.3 (C7); Anal. Calcd. for $\mathrm{C}_{24} \mathrm{H}_{20} \mathrm{FeN}_{2} \mathrm{O}_{3}$ (440.28): C, 65.47; H, 4.58; N, 6.36; Found: C: $65.62 ; \mathrm{H}: 4.51 ; \mathrm{N}, 6.45 \%$.

\subsubsection{Methyl (6S,Z)-4-oxo-5,6,7,12-tetrahydro-4H-cyclopenta[7,8]azonino[5,4-b]indole-6-carboxylate (13b)}

Light yellow powder. Yield: $0.096 \mathrm{~g}$ (6\% from 6b); $0.144 \mathrm{~g}(9 \%$ from 7b); $0.352 \mathrm{~g}$ (22\% by Method $L$ from 9b); 0,256 g (16\% by Method $L$ from 9b/inv); mp.: 198-201 ${ }^{\circ} \mathrm{C} ; R_{\mathrm{f}}: 0.24 ;[\alpha]_{\mathrm{D}}{ }^{25}:+18.2^{\circ}\left(\mathrm{CHCl}_{3} c=0.026\right.$ $\mathrm{g} / 100 \mathrm{~mL}) ; \mathrm{IR}\left(\mathrm{cm}^{-1}\right): \sim ~ 3300-2700,1746,1638,1536,1486,1353,1275,1251,1113,1094,958 ;{ }^{1} \mathrm{H}$ NMR $\left(\mathrm{CDCl}_{3}\right)$ : 9.25 (s, 1H, índole $\mathrm{NH}$ ); 7.42 (br d, $\left.J=7.7 \mathrm{~Hz}, 1 \mathrm{H}, \mathrm{H} 8\right) ; 7.37$ (br d, J=7.7 Hz, 1H, H11); 7.06 (td, $J=7.7$ Corresponding author: Tel.: +36 1372 2500/6591; Fax: +36 1372 2548; email: csampai@chem.elte.hu 
and $1.9 \mathrm{~Hz}, 1 \mathrm{H}, \mathrm{H} 10) ; 7.00$ (td, $J=7.7$ and $1.9 \mathrm{~Hz}, 1 \mathrm{H}, \mathrm{H} 9) ; 6.70$ (br s, 1H, H13); 6.76 (br d, J=4.6 Hz, 1H, H3);

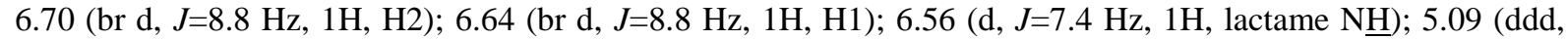
$J=7.4,5.5$ and $2.5 \mathrm{~Hz}, 1 \mathrm{H}, \mathrm{H} 6) ; 3.68\left(\mathrm{~s}, 3 \mathrm{H}, \mathrm{CO}_{2} \underline{\mathrm{CH}}_{3}\right) ; 3.45\left(\mathrm{dd}, J=14.7\right.$ and $\left.5.5 \mathrm{~Hz}, 1 \mathrm{H}, \mathrm{H} 7_{\mathrm{B}}\right) ; 3.39(\mathrm{dd}, J=14.7$ and $2.5 \mathrm{~Hz}, 1 \mathrm{H}, \mathrm{H} 7 \mathrm{~A}) ;{ }^{13} \mathrm{C}$ NMR $\left(\mathrm{CDCl}_{3}\right)$ : $173.0\left(\mathrm{CO}_{2} \mathrm{CH}_{3}\right) ; 166.7((\mathrm{C} 4) ; 135.8(\mathrm{C} 13 \mathrm{a}) ; 132.3(\mathrm{C} 11 \mathrm{a}) ; 130.4$ (C12a); 127.6 (C7b); 123.5 (C13); 122.6 (C10); 122.1 (C1); 120.2 and 120.1 (C2 and C3); 119.4 (C9); 118.8 (C8); 114.5 (C3a); 111.8 (C11); 110.1 (C7a); $54.3\left(\mathrm{CO}_{2} \mathrm{CH}_{3}\right) ; 52.7$ (C6); 28.0 (C7);

Anal. Calcd. for $\mathrm{C}_{19} \mathrm{H}_{16} \mathrm{~N}_{2} \mathrm{O}_{3}$ (320.35): C, 71.24; H, 5.03; N, 8.74; Found: C: 71.39; H: 4.97; 8.68\%.

\subsubsection{Methyl 7-oxo-7H-ferroceno[c]indolo[3,2,1-ij][1,5]naphthyridine-2-carboxylate (14b)}

Deep red solid. Yield: $0.480 \mathrm{~g}(22 \%$ from $7 \mathbf{b}) ; 0.654 \mathrm{~g}(30 \%$ from $8 \mathbf{b}) ; \mathrm{mp} .: 202-203{ }^{\circ} \mathrm{C} ; R_{\mathrm{f}}: 0.82$; $[\alpha]_{\mathrm{D}}^{25}:+32.0^{\circ}\left(\mathrm{CHCl}_{3} c=0.051 \mathrm{~g} / 100 \mathrm{~mL}\right) ; \mathrm{IR}\left(\mathrm{cm}^{-1}\right): 2894,1722,1673,1571,1440,1412,1375,1297,1250$, 1197,1180, 1012, 806, 791; ${ }^{1} \mathrm{H}$ NMR $\left(\mathrm{CDCl}_{3}\right): 8.90$ (s, 1H, H1); 8.62 (br d, $J=7.9 \mathrm{~Hz}, 1 \mathrm{H}, \mathrm{H} 9$ ); 8.51 (br d, $J=7.9$ $\mathrm{Hz}, 1 \mathrm{H}, \mathrm{H} 12) ; 7.79$ (td, $J=7.9$ and $1.8 \mathrm{~Hz}, 1 \mathrm{H}, \mathrm{H} 10) ; 7.59$ (td, $J=7.9$ and $1.8 \mathrm{~Hz}, 1 \mathrm{H}, \mathrm{H} 11$ ); 5.64 (dd, $J=2.5$ and $1.6 \mathrm{~Hz}, 1 \mathrm{H}, \mathrm{H} 4) ; 5.44(\mathrm{dd}, J=2.5$ and $1.6 \mathrm{~Hz}, 1 \mathrm{H}, \mathrm{H6}) ; 5.02(\mathrm{t}, J=2.5 \mathrm{~Hz}, 1 \mathrm{H}, \mathrm{H} 5) ; 4.12\left(\mathrm{~s}, 5 \mathrm{H}, \eta^{5}-\mathrm{C}_{5} \underline{\mathrm{H}}_{5}\right) ; 4.00(\mathrm{~s}$, $\left.3 \mathrm{H}, \mathrm{OCH}_{3}\right) ;{ }^{13} \mathrm{C}$ NMR $\left(\mathrm{CDCl}_{3}\right): 167.2(\mathrm{C} 7) ; 166.0\left(\mathrm{CO}_{2} \mathrm{CH}_{3}\right) ; 146.4(\mathrm{C} 2) ; 142.7(\mathrm{C} 3 \mathrm{a}) ; 139.0(\mathrm{C} 8 \mathrm{a}) ; 133.5$ (C12c); 131.1 (C10); 125.4 (C11); 125.0 (C12a); 124.0 (C12b); 123.9 (C12); 116.6 (C9); 116.5 (C1); 81.6 (C3b); 74.7 (C5); $73.6(\mathrm{C} 6 a) ; 71.7\left(\eta^{5}-\underline{\mathrm{C}}_{5} \mathrm{H}_{5}\right) ; 70.0(\mathrm{C} 6) ; 67.8(\mathrm{C} 4) ; 53.0\left(\mathrm{CO}_{2} \underline{\mathrm{CH}}_{3}\right)$; Anal. Calcd. for $\mathrm{C}_{24} \mathrm{H}_{16} \mathrm{FeN}_{2} \mathrm{O}_{3}$ (436.25): C, 66.08; H, 3.70; N, 6.42; Found: C: 65.97; H: 3.62; N, 6.48\%.

4.7. Acylation of tryptamine with $\left(S_{p}\right)$-2-formylferrocenecarbonylfluoride $(10):$ synthesis of $\left(S_{p}\right)-N-(2-(1 H$-indol3-yl)ethyl)-2-formylferrocene-1-carboxamide (11) by Method J

The mixture of tryptamine $(1.601 \mathrm{~g}, 10 \mathrm{mmol}), \mathbf{1 0}(2.601 \mathrm{~g}, 10 \mathrm{mmol})$ and dry THF $(40 \mathrm{~mL})$ was stirred under argon at $25{ }^{\circ} \mathrm{C}$ for $24 \mathrm{~h}$ then evaporated to dryness. The residue was triturated with $20 \mathrm{~mL}$ of $\mathrm{EtOH}-\mathrm{H}_{2} \mathrm{O}$ (1:3), filtered off and dried to give amide 11 as a dark orange solid. Yield: $2.842 \mathrm{~g}(71 \%)$; mp.: $204-207{ }^{\circ} \mathrm{C}$; $[\alpha]_{\mathrm{D}}{ }^{25}:+34.2^{\circ}(\mathrm{EtOH} c=0.037 \mathrm{~g} / 100 \mathrm{~mL}) ; \mathrm{IR}\left(\mathrm{cm}^{-1}\right): \sim 3400-2700,1695,1641,1453,1337,1249,1226,1125$, 1104, 1020, 883, 827, 738; ${ }^{1} \mathrm{H}$ NMR (DMSO- $d_{6}$ ): 10.83 (br s, 1H, H1); 10.42 (s, 1H, C $\underline{H O}$ ); 8.54 (t, J=5.6 Hz, $1 \mathrm{H}, \mathrm{CON} \underline{\mathrm{H}}$ ); 7.62 (br d, J=7.8 Hz, 1H, H4); 7.35 (br d, J=7.8 Hz, 1H, H7); 7.23 (br d, J=2.0 Hz, 1H, H2); 7.08 (br t, $J=7.8 \mathrm{~Hz}, 1 \mathrm{H}, \mathrm{H6}$ ); 7.01 (br t, $J=7.8 \mathrm{~Hz}, 1 \mathrm{H}, \mathrm{H} 5$ ); 5.27 (dd, $J=2.6$ and $1.5 \mathrm{~Hz}, 1 \mathrm{H}, \mathrm{H} 5$ '); 4.95 (dd, $J=2.6$ and $\left.1.5 \mathrm{~Hz}, 1 \mathrm{H}, \mathrm{H} 3^{\prime}\right) ; 4.83\left(\mathrm{t}, J=2.6 \mathrm{~Hz}, 1 \mathrm{H}, \mathrm{H} 4{ }^{\prime}\right) ; 4.23\left(\mathrm{~s}, 5 \mathrm{H}, \eta^{5}-\mathrm{C}_{5} \mathrm{H}_{5}\right) ; 3.59$ and $3.53\left(2 \times m, 2 \times 1 \mathrm{H}, \mathrm{NCH}_{\mathrm{A}} \mathrm{H}_{\mathrm{B}}\right.$ and $\left.\mathrm{NCH}_{\mathrm{A}} \underline{\mathrm{H}}_{\mathrm{B}}\right) ; 2.99\left(\mathrm{t}, \mathrm{J}=7.3 \mathrm{~Hz}, 2 \mathrm{H}, \mathrm{CC}_{2}\right) ;{ }^{13} \mathrm{C}$ NMR (DMSO-d $\left.d_{6}\right): 196.2(\underline{\mathrm{CHO}}) ; 168.9(\underline{\mathrm{CONH}}) ; 137.2(\mathrm{C} 7 \mathrm{a})$; 128.2 (C4a); 123.6 (C2); 121.8 (C6); 119.2 and 119.1 (C4 and C5); 112.7 (C3); 112.3 (C7); 80.1 (C1'); 79.2 $\left(\mathrm{C} 2^{\prime}\right) ; 75.5\left(\mathrm{C}^{\prime}\right)$ ); 74.1 (C4'); $72.8\left(\mathrm{C} 3^{\prime}\right) ; 72.0\left(\eta^{5}-\underline{C}_{5} \mathrm{H}_{5}\right) ; 40.6\left(\mathrm{NCH}_{\mathrm{A}} \mathrm{H}_{\mathrm{B}}\right) ; 26.1\left(\mathrm{CCH}_{2}\right)$; Anal. Calcd. for $\mathrm{C}_{22} \mathrm{H}_{20} \mathrm{FeN}_{2} \mathrm{O}_{2}$ (400.26): C, 66.02; H, 5.04; N, 7.00; Found: C: 66.20; H: 5.12; N, 6.94\%.

\subsection{Ring inversion $\mathbf{9 b / i n v ~} \rightarrow \mathbf{9 b}$ monitored by ${ }^{l} H$-NMR spectroscopy}

Lactame 9b/inv $(0.044 \mathrm{~g}, 0.1 \mathrm{mmol})$ was dissolved in DMSO- $d_{6}(1 \mathrm{~mL})$ and the resulted solution was subjected to ${ }^{1} \mathrm{H}-\mathrm{NMR}$ studies. First the ${ }^{1} \mathrm{H}-\mathrm{NMR}$ spectrum was registered at $300 \mathrm{~K}$, then solution was incubated at $363 \mathrm{~K}$ for ca. $30 \mathrm{~min}$ then cooled down to $300 \mathrm{~K}$, and the ${ }^{1} \mathrm{H}-\mathrm{NMR}$ spectrum registered showed the presence of inverted lactame $\mathbf{9 b}$ contaminated with a small amount (ca. 3-5\%) of $\mathbf{9 b} / \mathbf{i n v}$.

9b/inv: ${ }^{1} \mathrm{H}$ NMR (DMSO-d $)_{6}$ ): 10.75 (br s, $1 \mathrm{H}, \mathrm{NH}$, índole), 7.45 (br d, J=7.6 Hz, 1H, H8); 7.29 (br d, $J=7.6 \mathrm{~Hz}, 1 \mathrm{H}, \mathrm{H} 11$ ); 7.20 (br t, $J=7.6 \mathrm{~Hz}, 1 \mathrm{H}, \mathrm{H} 10$ ); 7.13 (td, $J=7.7$ and $1.8 \mathrm{~Hz}, 1 \mathrm{H}, \mathrm{H} 9$ ); 6.08 (s, 1H, H12b); $5.55\left(\mathrm{~d}, J=7.3 \mathrm{~Hz}, 1 \mathrm{H}, \mathrm{H6}_{\mathrm{A}}\right) ; 5.02$ (br s, $\left.1 \mathrm{H}, \mathrm{H} 1\right) ; 4.65$ (br s, $\left.1 \mathrm{H}, \mathrm{H} 3\right) ; 4.22\left(\mathrm{~s}, 5 \mathrm{H}, \eta^{5}-\mathrm{C}_{5} \underline{\mathrm{H}}_{5}\right) ; 4.30$ (t, $J=2.0 \mathrm{~Hz}$, $1 \mathrm{H}, \mathrm{H} 2) ; 3.76\left(\mathrm{~s}, 3 \mathrm{H}, \mathrm{CO}_{2} \underline{\mathrm{C}}_{3}\right) ; 3.51$ (d, J=15.6 Hz, 1H, H7 $\left.{ }_{\mathrm{B}}\right) ; 3.18\left(\mathrm{dd}, J=15.6\right.$ and $\left.7.3 \mathrm{~Hz}, 1 \mathrm{H}, \mathrm{H} 7_{\mathrm{A}}\right) ; 7.50$ (br $\mathrm{d}, J=7.7 \mathrm{~Hz}, 1 \mathrm{H}, \mathrm{H} 8) ; 7.35$ (br d, $J=7.7 \mathrm{~Hz}, 1 \mathrm{H}, \mathrm{H} 11) ; 7.19$ (td, $J=7.7$ and $1.8 \mathrm{~Hz}, 1 \mathrm{H}, \mathrm{H} 10) ; 7.13$ (td, $J=7.7$ and $1.8 \mathrm{~Hz}, 1 \mathrm{H}, \mathrm{H} 9) ; 6.30$ (s, 1H, H12b); 5.64 (d, J=7.1 Hz, 1H, H6 A $_{4} 4.94$ (br s, 1H, H1); 4.70 (br s, 1H, H3); 4.31 $\left(\mathrm{s}, 5 \mathrm{H}, \eta^{5}-\mathrm{C}_{5} \underline{\mathrm{H}}_{5}\right) ; 4.29(\mathrm{t}, J=2.0 \mathrm{~Hz}, 1 \mathrm{H}, \mathrm{H} 2) ; 3.78\left(\mathrm{~s}, 3 \mathrm{H}, \mathrm{CO}_{2} \mathrm{CH}_{3}\right) ; 3.41\left(\mathrm{~d}, J=15.9 \mathrm{~Hz}, 1 \mathrm{H}, \mathrm{H} 7_{\mathrm{B}}\right) ; 3.22(\mathrm{dd}$, $J=15.9$ and $\left.7.1 \mathrm{~Hz}, 1 \mathrm{H}, \mathrm{H} 7_{\mathrm{A}}\right)$;

9b: ${ }^{1} \mathrm{H}$ NMR (DMSO-d $d_{6}$ ): 10.54 (s, $1 \mathrm{H}, \mathrm{NH}$, indole); 7.52 (br d, $\left.J=7.6 \mathrm{~Hz}, 1 \mathrm{H}, \mathrm{H} 8\right) ; 7.40$ (br d, $J=7.6$ $\mathrm{Hz}, 1 \mathrm{H}, \mathrm{H} 11$ ); 7.06 (br t, J=7.6 Hz, 1H, H10); 6.98 (br t, J=7.6 Hz, 1H, H9); 5.94 (s, 1H, H12b); 4.85 (br s, 1H, $\mathrm{H} 1) ; 4.59$ (br s, $1 \mathrm{H}, \mathrm{H} 3) ; 4.28\left(\mathrm{~s}, 5 \mathrm{H}, \eta^{5}-\mathrm{C}_{5} \underline{\mathrm{H}}_{5}\right) ; 4.21(\mathrm{t}, J=2.0 \mathrm{~Hz}, 1 \mathrm{H}, \mathrm{H} 2) ; 4.26$ (dd, $J=11.3$ and $4.6 \mathrm{~Hz}, 1 \mathrm{H}$, $\left.\mathrm{H}_{\mathrm{A}}\right) ; 4.05\left(\mathrm{~s}, 3 \mathrm{H}, \mathrm{CO}_{2} \mathrm{CH}_{3}\right) ; 3.31\left(\mathrm{dd}, J=15.7\right.$ and $\left.11.3 \mathrm{~Hz}, 1 \mathrm{H}, \mathrm{H} 7_{\mathrm{B}}\right) ; 3.11\left(\mathrm{dd}, J=15.7\right.$ and $4.6 \mathrm{~Hz}, 1 \mathrm{H}, \mathrm{H} 7_{\mathrm{A}}$ ). These signals were practically identical to those discernible in the ${ }^{1} \mathrm{H}-\mathrm{NMR}$ spectrum of an original sample of $\mathbf{9 b}$ registered in DMSO- $d_{6}$ solution in a separate experiment.

Corresponding author: Tel.: +36 1372 2500/6591; Fax: +36 1372 2548; email: csampai@chem.elte.hu 
4.9. Imidazole-mediated ring enlargement of lactames $\mathbf{9 b}$ and $\mathbf{9 b / i n v}$ associated with the decomposition of the ferrocene residue: synthesis of $\mathbf{1 3 b}$ by Method $L$.

The corresponding lactame $(0.440 \mathrm{~g}, 1 \mathrm{mmol})$ and imidazole $(0.082 \mathrm{~g}, 1.2 \mathrm{mmol})$ were dissolved in DMF $(4 \mathrm{~mL})$. The solution was stirred at $110^{\circ} \mathrm{C}$ for 20 min under argon. The dark reaction mixture was poured onto cold water $(30 \mathrm{~mL})$ and the resulted suspension was extracted with DCM $(3 \times 40 \mathrm{~mL})$. The combined organic phase was washed with water $(5 \times 50 \mathrm{~mL})$, dried over $\mathrm{Na}_{2} \mathrm{SO}_{4}$ and evaporated to dryness. The dark solid residue was subjected to flash column chromatography over silica using DCM-MeOH (10:1) as eluent. The evaporation of the first orange band recovered $9 \mathbf{b}$ as evidenced by ${ }^{1} \mathrm{H}$ NMR data practically identical to those presented in section 4.5.2. Yield: $0.251 \mathrm{~g}(57 \%$ from $9 \mathrm{~b})$ and $0.216 \mathrm{~g}$ (49\% from 9b/inv). (Under the employed conditions ring inversion 9b/inv $\rightarrow \mathbf{9 b}$ obviously accompanies the conversion leading to $\mathbf{1 3 b}$.) Changing eluent to DCM$\mathrm{MeOH}(5: 1)$ allowed the isolation of $\mathbf{1 3 b}$ as light yellow powder. Yield: $0.070 \mathrm{~g}(22 \%$ from $\mathbf{9 b})$ and $0.051 \mathrm{~g}$ ( $16 \%$ from $9 \mathrm{~b} / \mathbf{i n v})$. The analytical and spectral data were practically identical to those measured for the sample prepared by Method $I$ (cf. section 4.6.5).

\section{Acknowledgements}

This work was financially supported by the Hungarian Scientific Research Fund (OTKA K68887) and the European Union and the European Social Fund (grant agreement no. TÁMOP 4.2.1/B09/KMR-2010-0003).

\section{References}

1. L. T. D. Tonin, V. A. Barbosa, C. C. Bocca, E. R. F. Ramos, C. V. Nakamura, W. F. da Costa, E. A. Basso, T. U. Nakamura, M. H. Sarragiotto, Eur. J. Med. Chem. 44 (2009) 1745.

2. Y-H. Wang, J-G. Tang, R-R. Wang, L-M. Yang, Z-J. Dong, L. Du, X. Shen, J-K. Liu, Y-T. Zheng, Biochem. Biophys. Res. Commun., 355 (2007) 1091.

3. L. Gupta, K. Srivastava, S. Singh, S. K. Puri, P. M. S. Chauhan, Bioorg. Med. Chem. Lett., 18 (2008) 3306.

4. A. Kumar, S. B. Katiyar, S. Gupta, P. M. S. Chauhan, Eur. J. Med. Chem. 41 (2006) 106.

5. P. Rivas, B. K. Cassels, A. Morello, Y. Repetto, Comp. Biochem. Physiol. C, 122 (1999) 27.

6. L. Zheng, H. Chen, X. Han, W. Lin, X. Yan, J. World, Microbiol. Biotechnol. 21 (2005) 201.

7. H. Guan, H. Chen, W. Peng, Y. Ma, R. Cao, X. Liu, A. Xu, Eur. J. Med. Chem. 41 (2006) 1167.

8. Q. Wu, R. Cao, M. Feng, X. Guan, C. Ma, J. Liu, H. Song, W. Peng, Eur. J. Med. Chem. 44 (2009) 533.

9. Y.-C. Shen, C.-Y. Chen, P.-W. Hsieh, C.-Y. Duh, Y-M. Lin, C-L. Ko, Chem. Pharm. Bull. 53 (2005) 32.

10. R. Cao, W. Peng, H. Chen, X. Hou, H. Guan, Q. Chen, Y. Ma, A. Xu, Eur. J. Med. Chem. 40 (2005) 249.

11. J. Ishida, H-K. Wang, K. F. Bastow, C-Q. Hu, K-H. Lee, Bioorg. Med. Chem. Lett. 9 (1999) 3319.

12. R. Cao, H. Chen, Y. Ma, X. Hou, H. Guan, X. Liu, A. Xu, Eur. J. Med. Chem. 40 (2005) 991.

13. R. Cao, Q. Chen, X. Hou, H. Chen, H. Guan, Y. Ma, W. Peng, A. Xu, Bioorg. Med. Chem. 12 (2004) 4613.

14. M. Zhao, L. Bi, W. Wang, C. Wang, M. Baudy-Floc'h, J. Ju, S. Peng, Bioorg. Med. Chem. 14 (2006) 6998.

15. R. Cao, W. Peng, H. Chen, Y. Ma, X. Liu, X. Hou, H. Guan, A. Xu, Biochem. Biophys. Res. Commun. 338 (2005) 1557.

16. Y. Boursereau, I. Coldham, Bioorg. Med. Chem. Lett. 14 (2004) 5841.

17. S. Xiao, W. Lin, C. Wang, M. Yang, Bioorg. Med. Chem. Lett. 11 (2001) 437.

18. A. M. Deveau, M. A. Labroli, C. M. Dieckhaus, M. T. Barthen, K. S. Smith, T. L. Macdonald, Bioorg. Med. Chem. Lett. $11(2001) 1251$.

19. Y. Song, D. Kesuma, J. Wang, Y. Deng, J. Duan, J. H. Wang, R. Z. Qi, Biochem. Biophys. Res. Commun. 317 (2004) 128.

20. Y. Song, J. Wang, S. F. Teng, D. Kesuma, Y. Deng, J. Duan, J. H. Wang, R. Z. Qi, M. M. Sim, Bioorg. Med. Chem. Lett. 12 (2002) 1129.

21. C. Biot, G. Glorian, L. A. Maciejewski, J. S. Brocard, J. Med. Chem. 40 (1997) 3715.

22. K.E. Dombrowki, W. Baldwin, J. E. Sheats., J. Organomet. Chem. 302 (1986) 281.

23. P. Köpf-Maier, H. Köpf-Maier, Chem. Rev. 87 (1987) 1137.

24. E. W. Neuse, M. G. Meirim, N.F. Blam, Organometallics 7 (1988) 2562.

25. S. Top, A. Vessiéres, C. Cabestaing, I. Laios, G. Leclerq, C. Provot, G. Jaouen, J. Organomet. Chem. 637-639 (2001) 500.

26. G. Jaouen, S. Top, A. Vessičres, R. Alberto, J. Organomet. Chem. 600 (2000) 23.

27. H. Ma, Y. Hou, Y. Bai, J. Lu, B. Yang, J. Organomet. Chem. 637-639 (2001) 7427.

28. L. Delhaes, H. Abessolo, C. Biot, L. Berry, P. Delcourt, L. Maciejewski, J. Brocard. D. Camus, D. Dive, Parasitol. Res. 87 (2001) 239.

29. B. Weber, A. Serafin, J. Michie, C. Van Rensburg, J. C. Swarts, L. Bohm, Anticancer Res. 24(2B) (2004) 763.

30. M. D. Joksovic, V. Markovic, Z. D. Juranic, T. Stanojkovic, L. S. Jovanovic, I. S. Damljanovic, K. M. Szécsényi, N. Todorovic, S.Trifunovic, R. D. Vukicevic J. Organomet. Chem., 694 (2009) 3935.

31. A. J. Corry, N. O’Donovan, , Á. Mooney, D. O'Sullivan, D. K. Rai, P. T.M. Kenny Organomet. Chem. 694 (2009) 880.

32. C. Ornelas, New J. Chem. 35 (2011) 1973, and references therein.

Corresponding author: Tel.: +36 1372 2500/6591; Fax: +36 1372 2548; email:

csampai@chem.elte.hu 
33. Á. Abrán, A. Csámpai, P: Sohár, Zs. Böcskei, Tetrahedron 55 (1999) 5441.

34. Á. Abrán, A. Csámpai, A. Kotschy, O. Barabás, P. Sohár, J. Mol. Structure 569 (2001) 185.

34. V. Kudar, V. Zsoldos-Mády, K. Simon, A. Csámpai, P. Sohár, J. Organomet. Chem. 690 (2005) 4018.

35. L. Găină, A. Csámpai, Gy. Túrós, T. Lovász, V. Zsoldos-Mády, I. A. Silberg, P. Sohár, Org. \& Biomol. Chem. 4 (2006) 4375.

36. Fábián, B.; Kudar, V.; Csámpai, A. Nagy, T. Zs. Sohár, P. J. Organomet. Chem., 2007, 692, 5621-5632.

37. Fábián, B.; Csámpai, A.; Nagy, T. Zs. Czugler, M.; Sohár, P. J. Organomet. Chem., 2009, 694, 3732-3741.

38. Gy. I. Túrós, A. Csámpai, M. Czugler, H. Wamhoff, P. Sohár, J. Organomet. Chem. 634 (2001) 122.

39. Gy. I. Túrós, A. Csámpai, T. Lovász, A. Györfi, H. Wamhoff, P. Sohár, Eur. J. Org. Chem. (2002) 3801.

40. A. Csámpai, Gy. I. Túrós, V. Kudar, K. Simon, H, Oeynhausen, H. Wamhoff and P. Sohár, Eur. J. Org. Chem. (2004) 717.

41. A. Csámpai, Gy. I. Túrós, A. Györfi, P. Sohár, J. Organomet. Chem. 694 (2009) 3667.

42. K. Kiss, A. Csámpai, P. Sohár, J. Organomet. Chem. 695 (2010) 1852.

43. E. Gál, C. Cristea, L. Silaghi-Dumitrescu, T. Lovász, A. Csámpai, Tetrahedron 66 (2010) 9938.

44. K. Kiss, V.-Ludovic Kocsis, T. Holczbauer, M. Czugler, L. Silaghi-Dumitrescu, A. Csámpai, J. Organomet. Chem. 726 (2013) 79.

45. A. Csámpai, Á. Abrán, V. Kudar, Gy. I. Túrós, H. Wamhoff, P. Sohár, J. Organomet. Chem. 690 (2005) 802.

46. Á. Gyömöre, A. Csámpai, J. Organomet. Chem. 696 (2011) 1626.

47. V. Zsoldos-Mády, A. Csámpai, R. Szabó, E. Mészáros-Alapi, J. Pásztor, F. Hudecz, P. Sohár, ChemMedChem. 1 (2006) 1119.

48. B. I. Károlyi, Sz. Bősze, E. Orbán, P. Sohár, L. Drahos, E. Gál, A. Csámpai, Molecules 17 (2012) 2316.

49. D. Csókás, I. Zupkó, B. I. Károlyi, L. Drahos, T. Holczbauer A. Palló, M. Czugler, A. Csámpai, J. Organomet. Chem. 2013. 743, 130-138.

50. D. Csókás, B. I. Károlyi, Sz. Bősze, I. Szabó, G. Báti, L. Drahos, A. Csámpai, J. Organomet. Chem. 2014, 750, 41-48.

51. (a) R. G. Parr, W. Yang, Density Functional Theory of Atoms and Molecules; Oxford, Univ. Press: New York, 1989; (b) T. Zeigler, Chem. Rew. 91 (1991) 651.

52. (a) A. D. Becke, J. Chem. Phys. 98 (1993) 5648;

(b) C. Lee, W. Yang, R. G. Parr, Phys Rev. B. 37 (1988) 785;

(c) P. J. Stephens, F. J. Devlin, C. F. Chahalowsky, M. J. Frisch, J. Phys. Chem. 98 (1994) 11623.

53. W. J. Hehre, L. Radom, P. V. R. Schleyer, J. A. Pople, Ab initio Molecular Orbital Theory; Wiley: New York, 1986.

54. (a) C. Peng, P. Y. Ayala, H. B. Schlegel, M. J. Frisch, J. Comp. Chem. 17 (1996) 49. (b) P. Y. Ayala, H. B. Schlegel, J. Chem. Phys. 107 (1997) 375.

55. K. Fukui, Acc. Chem. Res. 14 (1981) 363.

56. S. Miertus, E. Scrocco, J. Tomasi, J. Chem. Phys. 55 (1981) 117

57. K. Wolinski, J. F. Hilton, P. Pulay, J. Am. Chem. Soc. 112 (1990) 8251.

58. K. Raghavachari, J. S. Binkley, R. Seeger, J. A. Pople, J. Chem. Phys. 72 (1980) 650.

59. C. A. G. Haasnoot, F. A. A. M. DeLeeuw, C. Altona, Tetrahedron 36 (1980) 2783.

60. T. Vallant, J. Kattner, H. Brunner, U. Mayer, H. Hoffmann, Langmuir 15 (1999) 5339.

61. Gaussian 09, Revision A.02, M. J. Frisch, G. W. Trucks, H. B. Schlegel, G. E. Scuseria, M. A. Robb, J. R. Cheeseman, G. Scalmani, V. Barone, B. Mennucci, G. A. Petersson, H. Nakatsuji, M. Caricato, X. Li, H. P. Hratchian, A. F. Izmaylov, J. Bloino, G. Zheng, J. L. Sonnenberg, M. Hada, M. Ehara, K. Toyota, R. Fukuda, J. Hasegawa, M. Ishida, T. Nakajima, Y. Honda, O. Kitao, H. Nakai, T. Vreven, J. A. Montgomery, Jr., J. E. Peralta, F. Ogliaro, M. Bearpark, J. J. Heyd, E. Brothers, K. N. Kudin, V. N. Staroverov, R. Kobayashi, J. Normand, K. Raghavachari, A. Rendell, J. C. Burant, S. S. Iyengar, J. Tomasi, M. Cossi, N. Rega, J. M. Millam, M. Klene, J. E. Knox, J. B. Cross, V. Bakken, C. Adamo, J. Jaramillo, R. Gomperts, R. E. Stratmann, O. Yazyev, A. J. Austin, R. Cammi, C. Pomelli, J. W. Ochterski, R. L. Martin, K. Morokuma, V. G. Zakrzewski, G. A. Voth, P. Salvador, J. J. Dannenberg, S. Dapprich, A. D. Daniels, O. Farkas, J. B. Foresman, J. V. Ortiz, J. Cioslowski, and D. J. Fox, Gaussian, Inc., Wallingford CT, 2009.

Corresponding author: Tel.: +36 1372 2500/6591; Fax: +36 1372 2548; email: csampai@chem.elte.hu 